\title{
Vişegrad Grubu Üzerine Bir Analiz: Oluşumu, İşleyişi, Etkileri ve Sorunlar
}

DOI: 10.26466/opus.871140

\author{
* \\ Selim Yeșiltas * \\ * Dr. Öğr., Sakarya Üniversitesi, Siyasal Bilgiler Fakültesi, Sakarya/Türkiye \\ E-Posta: selimyesiltas@hotmail.com \\ ORCID: 0000-0001-6450-3465 \\ ** Araş. Gör. Dr., Trakya Üniversitesi İktisadi ve İdari Bilimler Fakültesi, Edirne/Türkiye \\ E-Posta: tolgaerdem@trakya.edu.tr \\ ORCID: 0000-0001-9354-2914
}

\section{Öz}

Vişegrad Grubu, kökeni oldukça eskilere dayanmakla birlikte 1991 yılında güncel halini alan Orta ve Doğu Avrupa iş birliği organizasyonudur. Bu çalışmada, Vişegrad Grubu'nun geçmişten günümüze kadar yaşadığı oluşum, işleyiş, etkiler ve sorunlar çok yönlü olarak analiz edilmektedir. Ayrıca Avrupa Birliği (AB) üyesi olan Vişegrad ülkelerinin Batı'ya entegrasyon süreci ve bu süreç içerisinde karşılaştıkları sorunlar detaylı olarak ele alınmaktadır. Grubun başlıca kuruluş amacı, komünizmin etkisinden kurtularak askeri ve ekonomik olarak Batı'ya tam uyum sağlamaktır. Ancak AB'ye tam üyelik sonrasında Avrupa içindeki uyum sorunlarında Vişegrad ülkelerinin de yer aldı̆̆ görülmektedir. 2014 yılındaki mülteci sorunu ve göç krizi ile 2016 yılında başlayan Brexit süreci, Vişegrad Grubu'nun AB içerisinde tam muhalif kimliğe dönüşmesine neden olmuştur. Diğer yandan, Grubun $A B^{\prime}$ 'den dışlandığını hissetmesiyle $A B$ ile yaşadığı sorunlar sürekli artma eğilimi göstermiştir. $B u$ bağlamda iki taraf arasındaki ilişkilerde yaşanan sorunlar ve AB'nin diyalog yaklaşımına rağmen söz konusu sorunların neden çözülemediği hususu, bu çalışmanın temel analiz kapsamını oluşturmaktadır.

Anahtar Kelimeler: Vişegrad Grubu, Vişegrad Dörtlüsü, V4, Avrupa Birliği, Entegrasyon. 


\title{
An Analysis on Visegrad Group: Formation, Functioning, Effects and Problems
}

\begin{abstract}
The Visegrad Group is a Central and Eastern European co-operation organization, which dates back to 1991, although its origins are long-established. In this study, the formation, operation, effects and problems experienced by the Visegrad Group from past to present are analyzed in a multidimensional way. In addition, the integration process of Visegrad countries to the West and the issues they face during this process are discussed in detail. The main purpose of the group was to get rid of the influence of communism and to fully adapt to the West, militarily and economically. However, it is seen that Visegrad countries are also involved in the problems of harmonization within Europe after full membership to the EU. The refugee issue and migration crisis in 2014, and beginning of the Brexit process in 2016, has caused the Visegrad Group to become a full opposition character within the EU. On the other hand, as the group felt excluded from the EU, its problems with the EU tended to increase continuously. In this context, the problems in the relations between the two sides and the reason why these problems cannot be solved despite the dialogue approach of the European Union constitute the main analysis scope of this study.
\end{abstract}

Keywords: The Visegrád Group, Visegrád Four, V4, The European Union, Integration. 


\section{Giriş}

"Vişegrad Grubu" olarak tabir edilen Polonya, Macaristan, Çekya ve Slovakya ülkeleri, üyesi oldukları Avrupa Birliği (AB) ile son zamanlarda ciddi seviyelerde gerilim yaşamaktadır. Oysa Grubun 1991 yılında belirlediği ortak hedeflerin en başında $A B^{\prime}$ ye uyum sağlamak ve tam üye olmak gelmiştir. Bu doğrultuda kurulan Grup, gerektiğinde $\mathrm{AB}^{\prime}$ ye bireysel uyum çalışmalarını hızlandırmak için Grubu pasifize dahi etmiştir. Ancak diğer yandan Vişegrad ülkeleri 2004 yılında Birliğe üye olduktan sonra Birliğin bütünleşme çabalarında çoğunlukla engel teşkil etmişlerdir. Çeşitli gerekçelerle antlaşmalarda opt out (dişında kalma) haklarını kullanan üyeler, genel olarak diyalog yoluyla AB'nin entegrasyon sürecinin içerisinde tutulmuştur. Ancak 2014 yılına kadar süren olumsuz gelişmelerin diyalog yoluyla çözülme süreci, mülteci kriziyle önü alınamayan sorunları beraberinde getirmiştir. Bu tarihten itibaren Vişegrad Dörtlüsü (V4) ülkeleri $A B$ ile en sorunlu döneme girmişlerdir. Arap Baharı ile Avrupa'ya mülteci akışının artması, Avrupa'da önü alınamayan sorunlara neden olmuş ve V4 üyeleri AB'nin büyük güçleri olan Almanya, Fransa gibi ülkelerin karşısında durmaktan çekinmemişlerdir. Mültecilerin AB içerisinde dağıtılması anlamına gelen "zorunlu mülteci kota uygulaması" ile kendilerine yapılan dayatmaları kabul etmeyen üyeler zamanla diğer ülkelerin muhalif gruplarından da destek görmüş ve kota uygulamasının zorunluluğunun iptalini sağlamışlardır. Ancak devamında Polonya, AB ile yargı reformu krizi, Macaristan ise $A B$ ile medya baskısı krizi yaşamıştır. $B u$ sorunlar gündeme - $\mathrm{AB}$ Temel antlaşmasının 7. maddesi kapsamında- özgürlük karşıtlı̆̆ durumunda ülkelerin karar mekanizması dışında bırakılmasını getirmiştir. Bunun üzerine bahsi geçen ülkeler zorunlu kota sistemine atıf yaparak sorunun siyasi olduğunu açıklamış ve kriz derinleşmiştir. Diğer yandan 2016 yılında Brexit referandumunun yapılması ile V4 üyeleri, $A B$ içerisinde Almanya ve Fransa'nın pro-Avrupacı politikası karşısında denge gücü oluşturan İngiltere'yi kaybetme tehlikesi ile karşılaşmıştır. Bu durum V4 üyelerinin $\mathrm{AB}^{\prime}$ den dışlanma hissiyatlarını, grup içerisinde ise dayanışmayı artırmıştır. Dolayısıyla Grup, bir yandan $\mathrm{AB}$ ile en sorunlu dönemini yaşarken diğer yandan da kendi içerisinde en iyi dönemini yaşamaya başlamıştır. Krizler genel olarak 
derinleştikçe, $A B$ içerisinde yeni muhalif cephe olarak V4 ortaya çıkmıştır. V4, $\mathrm{AB}$ tarafından entegrasyon hamlelerine uymamakla suçlanırken; $\mathrm{AB}^{\prime}$ yi ulusal kimliği yok etmekle suçlamıştır.

$\mathrm{Bu}$ çalışmanın amacı; Vişegrad ülkelerinin $\mathrm{AB}$ entegrasyon sürecinde $A B$ ile yaşadığı uzlaşmazlıkların entegrasyon sürecine verdiği zararın düzeyini belirlemektir. $\mathrm{Bu}$ bağlamda öncelikli olarak Vişegrad Grubu'nun oluşumu ve işleyişine dair genel bilgiler sunulacak, ardından Vişegrad Grubu'nun AB'ye ve Orta ve Doğu Avrupa'ya yansımaları irdelenecek, nihayetinde de Vişegrad Grubu'nun hem kendi içerisinde hem de $\mathrm{AB}^{\prime}$ yle olan ilişkilerinde sağladığı faydalar ve karşılaştığı sorunlar birlikte detaylandırılacaktır. Ayrıca tarafların yaşanan sorunlarda takındıkları tavırlar da ortaya konularak, oluşan sorunların geleceğine dair tespitlerde bulunulacaktır.

\section{Vişegrad Grubu: Oluşumu ve İşleyişi}

"Vişegrad Dörtlüsü", “V4", "Vişegrad Ülkeleri” veya "Vişegrad Girişimi" olarak da bilinen "Vişegrad Grubu", coğrafi açıdan Orta Avrupa (Central Europe) olarak adlandırılan bölgede bulunmaktadır. Grup "Vişegrad" ismini Macaristan'da bulunan aynı isimli kentten almıştır (Visegrad Group, 2019, https://www.diplomatie.gouv.fr/fr/). Grubun tarihi çok eskiye dayanmakla beraber en eski ekonomik ve siyasi işbirliklerinden biri olarak göze çarpmaktadır. İlk olarak 1335 yılında Macar Kralı I. Charles'ın ev sahipliğinde Macaristan'ın Vişegrad kasabasında toplanılmıştır. "Vişegrad Kongresi" olarak bilinen toplantının diğer katılımcıları Bohemya Kralı John ve Polonya Kralı III. Kazimir'dir. Toplantı devletlerarası sorunları çözmek, güvenliği sağlamak, işbirliğine gitmek ve dostluğu geliştirmek amaçlarıla yapilmiştır (History of the Visegrad Group, t.y., http://www.visegradgroup.eu/). Bugünkü Vişegrad Grubu'nun temellerinin dayandığı bu toplantı sayesinde günümüze kadar genel olarak eşgüdümlü politika izlemişlerdir. 


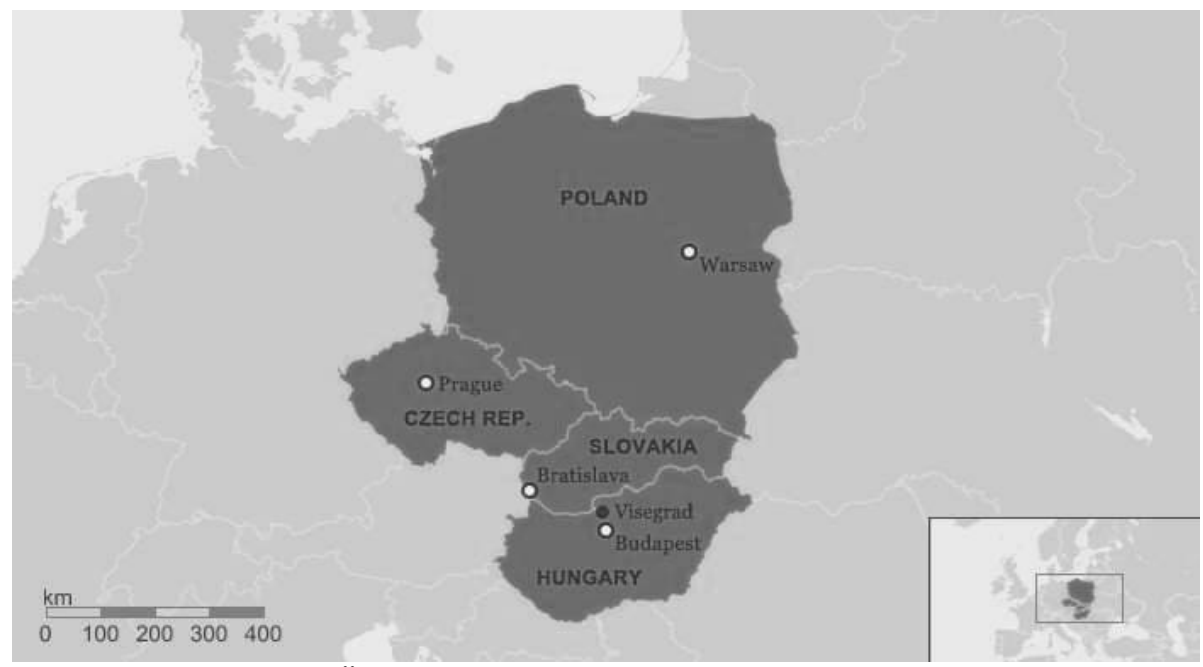

Harita 1: Vişegrad Ülkelerinin Avrupa'daki Konumu (Deutsche Welle, "Visegrad Countries Urge Stronger EU Border Defense", 21.06.2018, wwww.dw.com , (Erişim

Tarihi: 12 Nisan 2019).)

Orta Avrupa'da yer alan Vişegrad ülkeleri jeopolitik konumları itibariyle de genel olarak aynı ülkelere karşı (Rus-Alman) aynı sebeplerle (istila-işgal) karşı karşıya gelmişler ve benzer istilaları birlikte karşılamaya çalışmışlardır. Onlarca yıl Sovyet Sosyalist Cumhuriyetler Birliği (SSCB) etkisi altında beraber yaşayan bu devletler Sovyetlerin dağılmasıyla yeniden bağımsızlıklarına ulaşmışlardır. Ortak tarihi paylaşan söz konusu ülkeler tek bir medeniyetin parçası olduklarını unutmamışlar ve Sovyetlerin dağılmasıyla birlikte yeniden bir araya gelmişlerdir (About the Visegrad Group, t.y., http://www.visegradgroup.eu/).

1991 yılında "Vişegrad Üçlüsü" olarak Çekoslovakya, Polonya ve Macaristan ülkelerince kurulan Grup, Çekoslovakya'nın "Çek Cumhuriyeti" ve "Slovakya" olarak iki ülkeye ayrılmasiyla beraber yapısını bozmamış ve iki ülkeyi de içinde barındırarak 1993 yılında "Vişegrad Dörtlüsü" ismini almıştır (Visegrad Group, 2018, https://www.gov.pl/web/diplomacy).

Yeni kurulan Grubun temel amaçları; işbirliği, dostluk ve güvenlik yaklaşımlarıyla eski oluşumu hatırlatmaktadır. Ayrıca eski düzenden kurtulma ve yeni düzene entegre olma arzusu, modern amaçların 
varlığını işaret etmektedir. Bu amaçlardan birincisi, Sovyetlerden ayrılan Grup üyelerinin yıllarca etkisi altında oldukları Komünizmin kalıntılarından kurtulmak olurken, ikincisi ise yeni sisteme güvenlik bağlamında Kuzey Atlantik Antlaşması Örgütü (NATO), ekonomik bağlamda ise $A B$ ile entegre olmaktır. Dolayısıyla bu örgütlere üye olmak temel amaçtır. Bu doğrultuda Grup üyeleri bildirilerinde girişimlerinin $\mathrm{AB}^{\prime}$ ye alternatif olmadığını, aksine $A B^{\prime}$ ye entegrasyon hızlarını arttırmak için varlığını devam ettirdiğini dile getirmişlerdir. Hatta V4, üyelerinin bireysel çalışmalarının $\mathrm{AB}^{\prime}$ ye üyeliklerini hızlandıracağı düşüncesiyle 1993 yılından 1998 yılına kadarki çalışmalarını pasifize etmiştir (Slovakia and V4, 2015, https://www.gov.pl/). İlişkiler canlandırıldıktan sonra grubun üç üyesi Polonya, Macaristan ve Çek Cumhuriyeti- 1999 yılında NATO üyesi olurken, Slovakya'nın üyeliği 2004 yılında gerçekleşmiştir. 1 Mayıs 2004 tarihinde ise dört ülke, $\mathrm{AB}^{\prime}$ ye tam üye olarak Grubun amaçlarını önemli düzeyde yerine getirmişlerdir (About the Visegrad Group, t.y., www.visegradgroup.eu/). Vişegrad üyelerinin güncel amaçlarına bakıldığında ise, bu amaçların grubun NATO ve AB içerisindeki konumunun güçlendirilmesi ve Grubun bahsedilen örgütlerle uyumunun arttırılması şeklinde olduğu göze çarpmaktadır (Visegrad Cooperation, 2019, www.mzv.cz/jnp/en/). Dolayısıyla uzun bir geçmişe sahip olan Grubun yıllar boyunca konjonktüre bağlı olarak amaçlarının değiştiğini görmek mümkündür.

Tıpkı AB gibi bölgesel üyeli bir örgüt olan Vişegrad Grubu, yine AB gibi "devletlerearası/hükümetlerarası (intergovermentalist)" nitelikte bir oluşumdur. Ancak etkisi itibariyle $\mathrm{AB}^{\prime}$ den ayrılmaktadır. $\mathrm{AB}$ küresel etkili bir örgütlenmeyken, Vişegrad Grubu daha ziyade $A B$ ilişkilerine önem vermesiyle bölgesel kalmaktadır (Kegley ve Blanton, 2015). Bu etkisini sürdürmek adına zirvelerini Başbakanlık düzeyinde yılda bir defa gerçekleştiren Grup, dönem başkanlığını da aynı düzeyde değiştirmektedir. Haziran ayında yapılan bu zirvelerde dönem başkanlıkları Grubun üye ülkeleri tarafından dönüşümlü olarak yapılmaktadır. 2018-2019 yılında Slovakya'nın dönem başkanlığını yaptı̆̆1 Grubun şu anki dönem başkanı Çekya'dır. Sonrasında ise Polonya ve Macaristan siralamasiyla devam edecektir (Presidency Program, t.y., www.visegradgroup.eu/). 
Diğer taraftan V4 ülkeleri, bölgesel işbirliğinin geliştirilmesi amacıyla 2000 yılında "Uluslararası Vişegrad Fonu"nu (The International Visegrad Fund) kurmuştur. Söz konusu fonun kaynağını üye ülkeler eşit ölçüde toplamda 8 milyon Avro ile desteklerken; ayrıca Almanya, Amerika Birleşik Devletleri (ABD) ve Kanada gibi devletler de 2012 yılından bu yana 10 milyon Avro katkıda bulunmuşlardır (Visegrand Fund, t.y., www.visegradfund.org). Fon karar organı olarak "Dışişleri Bakanları Konferansı" kurulmuş ve sekretarya işlerini onaylamak için yetkilendirilmiştir (Conference of Ministers, t.y., www.visegradfund.org). Bunların dışında Fon tarafından finanse edilecek projelerin onaylanması için "Büyükelçiler Konseyi" kurulmuştur (Council of Ambassadors, t.y., www.visegradfund.org). Son olarak ise, işlerin yürütülmesi için Sekreterlik oluşturulmuştur.

Söz konusu V4 ülkeleri çalışmada da değinildiği üzere AB ile siyasi birlikten ziyade ekonomik birlik istemektedirler. Bu doğrultuda tek başına hareket etmenin verimsizliğinin farkında olmalarından dolayı V4'e daha fazla değer vermeye çalışmaktadırlar. Ekonomik açıdan bu ülkelerin durumu hakkında bilgi sahibi olmak için ülkelerin genel durumunu bilmek gerekmektedir.

Tablo 1. Vişegrad Ülkeleri Hakkında Kıyaslamalı Veriler

\begin{tabular}{|c|c|c|c|c|c|c|}
\hline Ülkeler & $\begin{array}{l}\text { GSMH } \\
(\mathrm{mr} \$)\end{array}$ & $\begin{array}{l}\text { Kişi } \\
\text { baş1 } \\
\text { Gsmh } \\
(\$)\end{array}$ & $\begin{array}{l}\text { İşsizlik } \\
\text { (\%) }\end{array}$ & $\begin{array}{l}\text { İthalat- } \\
\text { İhracat } \\
\text { (Almanya- } \\
\text { \%) }\end{array}$ & $\begin{array}{l}\text { Nüfus } \\
\text { (mn) }\end{array}$ & $\begin{array}{l}\text { AB } \\
\text { bütçesine } \\
\text { Etkisi (mn } \\
€)\end{array}$ \\
\hline Polonya & 563 & 31.110 & 4.9 & $22-27$ & 37.9 & -13.481 \\
\hline Macaristan & 149 & 29.790 & 4.3 & $25-25$ & 9.7 & -5.624 \\
\hline Çekya & 231 & 37.870 & 3 & $29-31$ & 10.5 & -2.870 \\
\hline Slovakya & 104 & 33.600 & 7.9 & $19-22$ & 5.4 & -948 \\
\hline Toplam-Ort. & 1047 & --- & 5 & & 63.6 & -22.923 \\
\hline
\end{tabular}

Kaynak: Bu tablo, Türkiye Cumhuriyeti Avrupa Birliği Bakanlı̆̆ı (Avrupa Birliği Bütçesi, 2016, www.ab.gov.tr) ve Dünya Bankası'nın GSMH (GNI) ile Kişi başına düşen milli gelir (GNI Per Capita) (2018 GNI Datas, 2018, data.worldbank.org.) verilerinden derlenerek oluşturulmuştur.

Vişegrad ülkeleri teker teker analiz edildiğinde, ithalat ve ihracattaki en büyük partnerin Almanya olduğu göze çarpmaktadır. Almanya'nın GSMH'sı (4.105 trilyon Dolar), V4 ülkelerinin dört katı civarındadır. Ayrıca AB içerisinde kişi başına düşen milli gelirin 44.270 Dolar (2018 
GNI Datas, 2018, data.worldbank.org) olması ve V4 ülkelerinin bu ortalamanın altında kalması, söz konusu ülkeleri ticaret bakımından Almanya özelinde $\mathrm{AB}^{\prime}$ ye bağımlı kılmaktadır.

$\mathrm{AB}$ bütçesine en fazla destekte bulunan Almanya'nın tek başına 17.658 milyon Avro katkısı göz önünde bulundurulduğunda tek başına 22.923 milyon Avro destek alan V4, giderlerini karşılayamamaktadır. Bu noktada yine $A B$ bütçesine destek veren ve Brexit ile gündemde olan Birleşik Krallık'ın AB giderlerinin yüzde 6'sını karşılaması da hesaba katılınca Brexit'in V4 ülkeleri açısından önemi anlaşılmaktadır. Diğer yandan $\mathrm{AB}$ içerisinde net yararlanıcılar içerisinde birinci sırada Polonya yer alırken, diğer V4 üyeleri de tıpkı Polonya gibi net yararlanıcı ülke statüsündedir (Avrupa Birliği Bütçesi, 2016, www.ab.gov.tr). Tablo 1 genel olarak incelendiğinde V4 üyelerinin ekonomik anlamda $A B$ ile bağlantısının kesilmesinin mümkün olmadığı çok net olarak görülmektedir.

Genel hatlarıyla Vişegrad Grubu'nun işleyişi ve oluşumu ile ilgili verilerden sonra söz konusu grubun üyeleri hakkında bilgilendirme grubun gelişimi hakkında bizlere bilgi verecektir. Üye ülkelere değinilirken önce giriş yapılacak, daha sonra nüfus bilgileri, ülkelerin kendine özgü $\mathrm{AB}$ duruşu ve iç siyasi hayatı hakkında değerlendirme yapilacaktır.

\section{Polonya}

Kültürel ve politik bir ittifak olarak V4'ün en güçlü üyesi olan Polonya, aynı zamanda girişimin öncü ve yönlendirici devletidir. Geleneksel olarak Almanya ve Rusya ile geçmişte yaşadığ 1 kötü ilişkiler -1939 yılında Polonya'nın önce Almanya, sonra SSCB tarafından işgale uğraması gibi- dolayısıyla belirtilen ülkelere karşı her zaman güvenlik kaygısı içerisinde bulunmuş, kendi güvenliğini ve çıkarlarını koruyabilmek için V4 girişimine önem vermiştir. Her ne kadar daha önce de Weimar üçgeni (Weimar Üçgeni: Polonya, Almanya ve Fransa tarafından kurulan girişimin amacı Polonya'yı Batı Avrupa'ya entegre etmektir. Polonya'nın AB üyeliği sonrası yeni amaç belirleyememiş ve gündemden düşmüştür. Detaylı bilgi için bkz.: www.msz.gov.pl) girişimi ile birlikte Almanya ve Fransa ile aynı birlikte olmasına karşın 
burada tutunamayınca Merkez Avrupa birlikteliğine verdiği önem artmıştır (Weimar Triangle, t.y., www.gov.pl). Bu girişim sayesinde $A B^{\prime}$ den dışlanma hissiyatını yok etmek ve kendi istemedikçe $A B^{\prime}$ den ayrılmama imkanına sahip olmak istemiştir. Böylece son zamanlarda Vişegrad ülkelerinin $A B$ ile yaşadığı sorunlar neticesinde Rusya ile yakınlaşmayı kabul etmeyen tek V4 ülkesi olarak göze çapmaktadır.

Dünya Bankası (The World Bank) 2018 verilerine göre 38 milyon (Poland Population, 2019, data.worldbank.org) dolaylarında nüfusa sahip olan Polonya 2009 yılında AB'nin Schengen bölgesine dâhil olduktan sonra verdiği göçlerle nüfus kaybına uğramıştır. Özellikle İngiltere'ye verdiği 1 milyona yakın göç ile İngiltere'de "Polonyalı muslukçu algısı" oluşmuş ve bu anlamda $A B$ içerisinde en iyi ilişkilere sahip olduğu İngiltere ile de sorunlar yaşamıştır. $\mathrm{Bu}$ anlamda Göç sorununu sadece dışarıdan gelenlerin oluşturmadığı, aynı zamanda iç göçün de $A B$ için büyük problemlere neden olduğunu gösteren en önemli verilerden biri de İngiltere'de Brexit sürecinde kullanılan $A B$ içi göç sorunudur. $B u$ konuda İngiltere diş göçleri engelleyebildiğini dile getirirken Schengen dolayısıyla $\mathrm{AB}$ içi göçün önüne geçemediğini belirtmiştir. Akabinde Brexit sürecinin yaşanmaması için Almanya ve Fransa, $A B$ içi göç düzenlemesine gidileceğini açıklamış ve Polonya $A B$ içinde büyük ülkelerin çıkarları için küçük ülkelerin çıkarlarının hiçe sayıldığı algısına kapılmaya başlamıştır (Hekimler, 2017). Ayrıca Polonya, AB içinde Almanya ağırlığını dengeleyici güç olarak gördüğü İngiltere'nin Brexit sürecine tam anlamıyla karşı çıkmış bu sürecin tamamlanmasıyla kendisinin dışlanacağını hissederek V4 girişimine daha fazla değer vermeye başlamıştır.

Avrupa'da dini öğelere yoğun önem vermesiyle bilinen bu ülkede merkez sağın yükselmesiyle beraber ulusçuluk eğilimi artış göstermiştir. Mevcut iktidar partisinden önceki parti olan Sivil Demokrat'ın (Platforma Obywatelska, PO) muhafazakâr yapisı, 2015'ten bu yana iktidarda bulunan Hukuk ve Adalet Partisi'nin (Prawo i Sprawiedliwość, PIS) yapısına benzemektedir. $\mathrm{Bu}$ benzerliği dikkate alarak Polonya kamuoyunun düşünceleri hakkında bilgi sahibi olunabilmektedir. Ayrıca PIS'in Avrupa şüphecisi ve kürtaj karşıtı olması, AB ile sık sık karşı karşıya gelmesine neden olmaktadır. Özellikle $A B$ uyum programlarına karşı gelmekle yetinmeyen PISS hükümeti, daha önceki 
uyum programlarının ulusçuluğu yok ettiğini savunarak eleştirmektedir. 2014 yılından günümüze üç farklı hükümet ile başta bulunan partinin görüşlerinin halk tarafından kabul gördügünü söylemek mümkündür.

\section{Macaristan}

Macaristan, Vişegrad Grubu içerisinde $\mathrm{AB}^{\prime}$ ye en karşıt açıklamalar yapan ülke olarak bilinmektedir. Özellikle Fidecz Partisi genel başkanı Viktor Orbán'ın 2010 yılında ikinci defa iktidara gelmesi, Orbán'ı gelecek seçimler adına popülist uygulamalara itmiştir. Bu doğrultuda Orbán, $A B$ üyesi ve aynı zamanda da en büyük $A B$ şüphecisi olarak ön sırada yer almıştır. Bahsedilen şüpheciliğini söylemleri ve eylemleriyle gösteren Orbán $A B^{\prime}$ den karşıt söylemler almasına rağmen özellikle Polonya ile beraber hareket ederek, demokratik değerleri ihlal sonrasınde $\mathrm{AB}$ Konseyi'nde oy hakkının askıya alınmasını içeren 7. maddenin kullanımını engellemiştir. Ancak ortağı olarak gördüğü Polonya'dan farklı olarak Rusya ile yakın ilişkilere girmeyi istemektedir (Witte, 2019, www.washingtonpost.com).

Macaristan'ın 2018 nüfusu 9,7 milyon (Hungary Population, 2019, data.worldbank.org) olmakla beraber 1981 yılından bu yana gerek göç vererek, gerekse doğum oranlarının düşük olması sebebiyle yılda ortalama 40.097 nüfus kaybına uğramaktadır. Kaybın bu doğrultuda devam etmesi halinde ülke nüfusunun 2070 yılında 6 milyona düşeceği öngörülmektedir (Sonyai, 2019, hungarytoday.hu). Macaristan'ın iç sorun kabul ettiği nüfus kaybını bir türlü engelleyememesi ise akıllara dışarıdan gelebilecek insanların teşvik edilmesini getirmektedir. $\mathrm{Bu}$ durumda ülkeye gerçekleşen mülteci hareketliliklerinin nüfus açısından bir fırsat değil de seçimler için popülist amaçlı kullanılması mevcut nüfus sorunun çözümünü güçleştirmektedir.

Polonya'nın hem AB hem de Rusya karşıtı olması, Macaristan'ı tıpkı Çekya ve Slovakya gibi Polonya'nın lider rolünde olduğu Vişegrad içerisinde temkinli olmaya itmiştir. Ancak bir yandan mülteci sorununun büyümesi diğer yandan Brexit'in gündeme gelmesi gibi gelişmeler yaşanırken Macaristan, Polonya ile Vişegrad içerisinde ortak hareket eden ülke haline gelmiştir (Hekimler, 2017). 
2010 yılından günümüze ülke seçimlerini kazanan Fidecz Partisi lideri Victor Orbán'ın milliyetçi ve göç karşıtı politikaları yanında AB karşıtı yaptığ1 açıklamaların Partinin oy oranına artış yaptığı göz önüne alındığında, Macaristan'ın halk nezdinde de AB karşıtı olduğu öngörülebilir bir gerçekliktir (Avrupa ve Milliyetçilik: Avrupa Parlamentosu Seçimlerinde Milliyetçi ve Aşırı Sağcı Partiler 'Güç Bloğu' Oluşturma Çabasında, 2018, www.bbc.com). Özellikle AB'nin zorunlu kota uygulamasın 2016 yılında ülkesinde referanduma götüren Orbán, "vatandaşlarının \%98'inin mültecileri Macaristan'da istemediği" neticesini zafer olarak görmüş ve mülteci söylemlerini daha da sertleştirmiştir (Hungary PM Claims EU Migrant Quota Referandum Victory, 2016, www.bbc.com).

\section{Çekya}

Çekya, Vişegrad Grubu içerisinde AB yanlısı olarak bilinen iki ülkeden biridir. Özellikle Sovyetlerin dağılması ve $A B^{\prime}$ ye üye olmasından sonra özellikle ekonomik düzeyde kalkınmasını AB'ye borçludur. Ancak 2017 seçimlerinde önde olan iki partiden birinin Rus yanlısı olduğunu söylemek gerekir ki bu parti, ülkede adı yolsuzlukta geçen milyoner Andrej Babiş önderliğindeki ANO 2011'e (Akce nespokojenıch obcanuGayrimemnun vatandaşlar partisi) karşı seçimi kaybetmiştir (Klein, 2019, www.dw.com).

2018 verilerine göre 10 milyonun üzerinde nüfusa sahip olan Çekya'nın yarım asırdır nüfusu bu dolaylardadır (Czech Republic Population, 2019, data.worldbank.org). Polonya ve Macaristan'a göre daha istikrarlı bir nüfusa sahip olan ülkenin, bahsi geçen ülkelere göre nüfus sorunu kısmen bulunmamaktadır. Ancak nüfusun milliyetçi yapıda olması, ülkenin mülteci politikalarında sert söylem geliştirmesinde etkili olmuş ve $\mathrm{AB}$ yanlısı bir ülke olmasına karşın ülkeyi Vişegrad Grubu'na yakınlaştırmıştır.

Çekya, Brexit konusundan son derece rahatsız olan ülkelerin başında gelmektedir. Bir yandan İngiltere ile olan ticaretinin olumsuz etkileneceği görüşleri (Çekya'da Brexit Endişesi, 2019, www.ticaret.gov.tr) diğer yandan ise $A B^{\prime}$ ye önemli ölçüde ekonomik destekte bulunan Birleşik Krallık'ın AB'den ayrılmasının Çekya'ya 
yapılan yardımları etkileyeceği düşüncesi Çekya'yı endişelendirmektedir. Ayrıca Merkez Avrupa ülkelerine birçok anlamda katkıda bulunan Birleşik Krallık'ın ayrılması Çekya'yı Vişegrad Grubu'na daha fazla yaklaştırmaktadır (Brexit Çekya'yı ve Bölgeyi Nasıl Etkileyecek, 2018, ticaret.gov.tr).

Çekya merkez sağ iktidarının egemen olduğu ve bu doğrultuda kamuoyunda aşırı sağ hareketlerin karşılık bulduğu bir ülkedir. Günümüzdeki ANO 2011'in selefi olan parti Çek Sosyal Demokrat Parti (Česká Strana Sociálně Semokratická, ČSSD)'dir. Son olarak 2014-17 aras1 iktidarda bulunan parti, her ne kadar komünist kökenli olsa da özellikle 1993 sonrasında Avrupalı bir demokrasi partisine dönüşmüş ve 2000'den günümüze ara ara kendisine iktidarda yer bulmuştur (Czech Republic Political Parties, t.y., nsd.no/european_election_database). 2017 seçimlerinde ČSSD, büyüyen ekonomiye rağmen $\% 7.3$ oy alarak beşinci partiliğe kadar gerilemiştir. Seçimde sürpriz yaratan ve \%11.3 oy alarak ikinci olan parti, Rus yanlısı bir liderin başında bulunduğu Sivil Haklar Partisi (Strana Práv Občanů, SPO)'dir. Seçimi kazanan parti ise \%29.6 oyla ANO 2011 partisi olmuştur. Muhafazakâr ve merkez sağ olarak konumlandırılan parti, $\mathrm{AB}$ yanlısı olarak değerlendirilir; ancak uluşçuluk hareketleri nedeniyle mülteci politikası ve Avro bölgesi gibi birçok AB politikasına karşı çıkmaktadır (Çek Seçimlerinin Galibi Açık Ara ile Babiş, 2017, www.dw.com). Genel seçimleri kaybeden ancak 2018 yılı Başkanlık seçimlerini ikinci turda kazanan SPO (Strana prav obcanuToplumsal haklar partisi) lideri Milos Zeman ise Rus yanlısı olması itibariyle dikkat çekmektedir (Çekya'da Seçimleri Bir Kez Daha Zeman Kazand1, 2018, tr.sputniknews.com).

\section{Slovakya}

Slovakya tıpkı Çekya gibi grubun $\mathrm{AB}$ yanlısı olarak göze çarpan diğer ülkesidir. Özellikle Grubun içerisinde Avro bölgesinde olması itibariyle ekonomik alanda da $\mathrm{AB}^{\prime}$ ye en fazla ayak uydurmuş olan devlettir. Ancak Slovakya'nın Çekya'ya benzer ekonomik yolsuzluklarla AB gündemine gelmesi, ülke içerisinde haksızlık olarak nitelendirilerek $\mathrm{AB}$ şüpheciliğini giderek arttırmaktadır (Klein, 2019, www.dw.com). 
1990'l1 yıllardan bu yana nüfusu 5 milyon dolaylarında olan ülkenin nüfus artış hızı düşüktür (Slovak Republic Population, 2019, data.worldbank.org). Nüfusunun yaklaşık yüzde 10'u Macar azınlığ1 içeren Slovakya, azınlıklara karşı uyguladığı politikalar sebebiyle Macaristan ile karşı karşıya gelmiştir (Machacek, 2011). Özellikle Slovakya bağımsız olduktan sonra Macarların politikalarını irredentist algılamış ve azınlıklar karşısındaki tutumunu sertleştirmiştir. Günümüzde ise Slovakya'nın çıardığı Slovakya dil yasası ve Macaristan'ın 2010 yılında çıardığı çifte vatandaşlık yasaları, iki ülke arasındaki esas sorunları teşkil etmektedir (Saral, 2010). Ancak bu sorunlar, iki ülkenin V4 içerisinde karşıt duruşlar sergilemesine neden olmamıştır.

Slovakya 2012 ve 2018 seçimlerinde kazanan Yön ve Sosyal Demokrasi Partisi (Smer-Sociálna Demokracia, SMER-SD)'nin yönetimde olduğu bir ülkedir. Parti merkez sol partisi olmakla beraber bir yandan $A B$ yanlısı duruş sergilerken, bir yandan da göçmen karşıtlı̆̆ıyla ön plana çıkmakta ve bu özelliğiyle son zamanlarda kendisini Vişegrad Grubu'nun yanında konumlandırmaktadır (Direction-Social Democracy, t.y., www.ceeidentity.eu).

\section{Vişegrad Grubu: Etkileri ve Sorunlari}

20. yüzyılda Orta Avrupa'daki bölgesel işbirliği oluşturma çabaları, Orta Avrupa Girişimi (Central European Initiative, CEI) ve Orta Avrupa Serbest Ticaret Bölgesi (Central European Free Trade Area, CEFTA) gibi bazı olumlu girişimler olmasına rağmen çoğunlukla başarısız olmuştur. $\mathrm{Bu}$ bölgede işbirliğinin inşası, çeşitli nedenlerden -ekonomik, tarihi, politik ve etnik açıdan dezavantajlı koşullar- dolayı oldukça zor ve yavaş gerçekleşmiştir. Etkili ve verimli bir işbirliği anlayışı ve kültürünün oluşumu nispeten yakın dönemlerde başlamıştır (Szilágyi, 2014). Bu bağlamda Vişegrad Grubu'nun formasyonu, dört temel faktör üzerine motive edilmiştir: 1) Orta Avrupa'daki komünist bloğun kalıntılarını ortadan kaldırma isteği; 2) Orta Avrupa ülkeleri arasındaki tarihi düşmanlıkların üstesinden gelme arzusu; 3) Sosyal dönüşümün başarıyla gerçekleştirilerek Avrupa entegrasyon sürecine katılmak gibi belirlenen esas hedeflere ulaşabilmenin müşterek çabalarla daha kolay 
olacağı inancl; ve 4) İktidardaki siyasi seçkinlerin fikirlerinin yakınlığ (History of the Visegrad Group, t.y., www.visegradgroup.eu).

Vişegrad Grubu'nun bu dört temel motivasyon faktörü üzerinden ilk zamanlardaki temel ortak hedefleri ise demokrasiye ve ekonomiye yönelik reformları uygulayarak NATO ve AB'ye üye olmak şeklinde gerçekleşmiştir. Bilhassa Karşılıklı Ekonomik Yardımlaşma Konseyi'nin (The Council for Mutual Economic Assistance, COMECON) ve Varşova Paktı'nın (The Warsaw Pact, WAPA) çöküşünden sonra, bölge ülkelerinin devlet başkanları, Ortak Pazar (Common Market) ve diğer AvrupaAtlantik (Euro-Atlantic) kurumlarına üyelik elde edebilmek için yeni siyasi ve ekonomik işbirliği biçimlerine hızla yönelmişlerdir. SSCB'nin dağılması sonrası bu bölgeyle olan uzun vadeli ekonomik bağların da çökmesiyle birlikte Doğu pazarının uğradığı ekonomik kaybı karşılayabilmek adına doğrudan yabancı yatırımcıları, Batı'nın finansal ve mali yardımlarını ve hatta uzmanlığını çekebilmek, Vişegrad Grubu ülkelerinin temel amaçlarını oluşturmuştur (Jasiecki, 2016). Ancak V4 ülkelerinin resmi organizasyonel ve politik işbirliği yapılarının eksikliği, Atlantik yönelimi ve Doğu komşularıyla etkileşimci ve genişlemeci yapısı gibi spesifik özellikleri ile gruptaki ülkelerin sahip oldukları farklı vizyonlardan dolayı görüş farklılıklarının artması söz konusu olmuştur. Bu genişleyen sapma, aynı zamanda liderlerin Gruba yönelik görüşlerini de kapsamıştır. Örneğin; V4'e tahsis edilen bütçenin oldukça düşük miktarlarda -Uluslararası Vişegrad Fonu (The International Visegrad Fund, IVF) 2000 yılında yaklaşık 1 milyon Avro yıllık bütçeyle kurulmuş, 2010 yılında 6-7 milyon Avro'ya çıkmıştır (Balogova, 2009)- sunulması Grubun gücüne, olası etkilerine ve gelecekteki uygulanabilirliğine dair şüpheci yansımaları beraberinde getirmiştir (Jasiecki, 2016). Bu doğrultuda Vişegrad Grubu işbirliğinin ilk birkaç yılı, karşılıklı anlayış beklentileri ve umutları hakkında çeşitli şüphelerle sonuçlanmıştır. V4 ülkeleri, piyasa ekonomisine dönüşüm ile birlikte $N A T O$ 'ya ve $\mathrm{AB}^{\prime}$ ye katılarak Avrupa-Atlantik entegrasyonunu sağlama konusundaki nihai hedeflerine ilerlerken, bir taraftan da işbirliğine yönelik yeni soru işaretleri ve bölünmeler ortaya çıkmıştır. Sadece AB'ye katılım müzakereleri sırasındaki çıkar maksimizasyonuna bağlı rekabetçi tutumlar dikkate alındığında bile Grubun dayanışma, eşgüdüm fikirleri 
ve hayatta kalma şansına dair ciddi anlamda soru işaretleri oluşmaktadır (Lazar, 2014).

Vişegrad Grubu'nun AB'ye, Orta ve Doğu Avrupa'ya Yansımalarn: Vişegrad Grubu'nun Batı'yla işbirliğine yönelik bakış açısını sadece Avrupa-Atlantik yapıların sunmuş olduğu bağımsızlık, istikrar ve refah üyeliği vaatleri oluşturmamaktadır. Ayrıca bu Grubun oluşturulmasıyla Orta Avrupa içindeki söz konusu bölgenin Avrupa'ya aidiyet -Doğu'ya ya da Batı'ya ait olarak tanımlanamama- sorunu kısmen de olsa bir son bulmuştur. Bununla birlikte Vişegrad Dörtlüsü'nün tutkusu, Batı'nın sunduğu imkânların çok daha ötesine geçmektedir. Merkezi Doğu Avrupa (Central Eastern European) ülkeleri, kendi iç özgürleşmeleri başladıktan sonra NATO üyeliğine ilgi duymaya başlamıştır. Öyle ki dönemin Çekoslovakya Cumhurbaşkanı Václav Havel, 1991'in başlarında NATO'yu üyeliğini Merkezi Doğu Avrupa'ya açmaya çağırmıştır. Buna ek olarak 1992 yılında ise Polonya askeri doktrini güncellenirken, Polonya Savunma Bakanı Janusz Onyszkiwicz tarafından NATO üyeliği öncelikli hedef olarak kapsama alınmış ve Almanya ile işbirliği "Batı Avrupa'ya entegrasyon için en önemli yollardan biri" olarak tanımlanmıştır (Handl vd., 2000). Diğer taraftan Avrupa Topluluğu'nun Doğu'ya yönelik açılımı, Batı karşıtı milliyetçiliğin yeniden canlanmasına karşı teminat, siyasi ve ekonomik sürecin istikrara kavuşması açısından ise en stratejik hamlelerden biri olarak yorumlanmıştır. Öte yandan Vişegrad ülkelerinin NATO'ya dâhil edilmesi de Amerika'nın çıkarına olmuştur. Çünkü söz konusu ülkelerdeki dönemin liderleri aynı zamanda Amerikan yanlısı görünmektedir ve güvenlik konularındaki görüşleri ABD, İngiltere, Portekiz ve Hollanda gibi diğer Atlantikçi üyelerle yakından örtüşmektedir. Onların NATO'ya dâhil edilmesiyle ittifakın Atlantik oryantasyonu güçlenmiş ve ABD'nin kilit güvenlik konularındaki görüşlerine yönelik daha fazla iç destek sağlanmış olmaktadır (Asmus vd., 1993).

1990'ların başı itibariyle Merkezi Doğu Avrupa bölgesinin yeniden yapılandırılmasıyla ilgili tartışmalar giderek artmış, yeni sorular ve sorunlar ortaya çıkmıştır. SSCB'nin siyasi dönüşümü ve çöküşü göz önüne alındığında, tarihi ve dinamik güçler, bölgenin alan planlamasının 
(spatial) yeniden düzenlenmesini gerekli kılmıştır. "1989 Devrimleri" olarak da bilinen Doğu ve Orta Avrupa'yı derinden etkileyen devrim dalgası, Avrupa'nın uzamsal imajıla alakalı radikal bir yeniden düzenleme getirmiştir (Bialasiewicz, 2009). Ardından Polonya, Macaristan ve Çekoslovakya'nun yeni demokrasileri, Vişegrad Grubu'nun oluşumuyla sembolize edilen yeni bir Orta Avrupa işbirliği tarzını izlemeye başlamışlardır. Bu bölgenin tarihi ile ilgili eski tartışmaları ve yanlış anlamaları aşmaya çalışırlarken, başlangıçta üç (sonrasında ise dört) Merkezi Doğu Avrupa ülkesi lideri tamamen yeni olan bu işbirliği biçimine odaklanmaya başlamışlardır. Söz konusu bölgesel entegrasyon tarzı, tarihsel bağların ve güçlerin doğal bir sonucu olarak da yorumlanabilmektedir. Bu ülkelerin dönüşümüne ve yönlendirilmesine yardımcı olabilecek başka bir dışsal aktör bulunmadığından bölgesel entegrasyon son derece faydalı bir girişim olarak kabul edilmektedir (Schmidt, 2016). V4 ülkelerinin "1989'dan bu yana yaşadıkları siyasi ve ekonomik devrimlerin pekiştirilmesi" temel argümanı açısından da merkez kurumlarına üyelik yoluyla Batı ile entegrasyon sağlanması elzem olmuştur. Dahası bu devletler, Avrupa'da ortaya çıkan yeni güç dengelerine uyum sağlama süreciyle ve aynı zamanda güvenliklerine yönelik tarihsel tehditlerin yeniden ortaya çıkması endişesiyle ancak bu şekilde mücadele edebilmişlerdir. $\mathrm{Bu}$ sebeple V4 ülkelerinin NATO'ya ve $A B^{\prime}$ ye üyelikleri, hem iç hem de uluslararası güvenlik perspektifleri için çok önemli görülmüştür (Buteux, 1995).

Diğer taraftan V4 içindeki ilişkilerin derinleşmesi, güçlendirilmesi ve zenginleştirilmesi son derece önemlidir. Her ne kadar V4 ülkelerinin daha yakın işbirliğine yönelik nedenleri, $\mathrm{AB}$ üyeleri tarafından tamamen paylaşılmıyor olsa da Vişegrad Grubu, Orta Avrupa'daki bölgesel istikrarsızlı̆̆ın sınırlandırılarak, Batı Avrupa'yı Doğu'daki kitlesel göç gibi tehditlere karşı koruyacak ve Batı'nın istikrarını güvence altına alacak yepyeni bir karantina kuşağ görülmektedir (Inotaj ve Sass, 1994). Bu nedenle V4 ülkeleri arasındaki ilişkilerin olumlu yönde sürdürülmesi gerekliliği $A B$ açısından son derece değerlidir. Hatta bu durumun sağlanabilmesi, $A B$ açısından en önemli görevlerden biri olarak kabul edilmelidir. Bu bölgede istikrar ve düzen gerçekleştirildikten sonra $\mathrm{AB}^{\prime}$ nin Doğu Ortaklığı (The Eastern 
Partnership of the EU) ya da Batı Balkanlar ile ilişkilerinin nitelikli hale getirilerek daha ileriye gidilebilmesi gibi hedefler gerçekleştirilebilir (Szilágyi, 2014).

Vişegrad ülkeleri kendi aralarındaki rekabetten doğal olarak faydalanabilseler de, politika yapıcıları arasındaki çok fazla rekabet hali, daha kalitesiz ve işbirlikçi olmayan sonuçlara yol açabilmektedir. Bu noktada Vişegrad stratejistlerine yönelik iki argüman geliştirilebilmektedir: Birincisi, $\mathrm{AB}^{\prime}$ ye üye olmak demek, diğer oluşumlara dahil olmaktan daha iyi koşullar altında yer almak anlamına gelmeyebilir. İkincisi ise belirli bir çerçevede işbirliği ve politika koordinasyonu, özellikle küçük ülkeler söz konusu olduğunda ulusal çıkarların feda edilmesini mecburi kılmayabilir (Polackova, 1994). V4 ülkelerinin ayrı ayrı strateji tanımlamalarına bakıldığında ise George Kolankiewicz tarafından şu şekilde tasnif edildiği görülmektedir: Çeklerin stratejisi minimalist olarak tanımlanmaktadır. Buna göre Çekya, Orta Avrupa devletlerinin gruplandırılmasinı Orta Avrupa Serbest Ticaret Anlaşması (CEFTA) gibi çok taraflı bağlarla tamamlanan ikili ilişkilerin desteklendiği bir çeşit danışma organı olarak kabul etmektedir. Macarların duruşu ise esasen pragmatist ve araçsal olarak yorumlanmaktadır. Öyle ki Macarlar, Vişegrad'ı bir "örgüt”ten ziyade bir "süreç" olarak kabul etmişler ve Avrupa'ya erişim kazanabilmek adına Orta Avrupa Girişimi (CEI) gibi kuruluşlarla birlikte kullanabilmek için hazırlıklar yapmışlardır. Polonya'nın konumu ise maksimalist ve işseldir yani sadece kendi iyiliği için işbirliği anlayışındadır. Yalnızca Vişegrad'ı değil, aynı zamanda Ortak Avrupa Girişimi'ni de desteklemektedir. Ayrıca Avrupa ile entegrasyonunu ilerletebilmek için Baltık Konseyi ve Avrupa-Arktik grubu ile ikili anlaşmaları da önemsemektedir. Polonyalılar, kendilerini Vişegrad Grubu'nun arkasındaki hareketli ruh olarak görmekte ve bunun Rus çıkarlarının ötesinde tanımlanabilme adına anlaşılır olduğuna inanmaktadırlar. Son olarak ise Slovakya, Vişegrad'ı Batı'nın vazgeçilmez bir yaşam alanı şeklinde kabul etmektedir. Vişegrad Grubu, 1989 Devrimlerinin ekonomik sonuçlarının üstesinden gelmek ve kendi siyasi yapısını istikrara kavuşturmak için önde gelen demokrasilerle temas halinde kalabilme şansı olarak tanımlanmaktadır (Kolankiewicz, 1994). 
Vişegrad Grubu'nun Sağladiğı Faydalar ve Yaşadı̆̆ı Mevcut Sorunlar: V4 işbirliğinin ilk on yılına bakıldığında pek çok ihtilaf ve zorluk yaşandığı görülmektedir. İlk ihtilaf, 1991 yılının Ekim ayında Vişegrad Grubu'nun gerçekleştirdiği Krakov Zirvesi'nde ortaya çımıştır. Zirvede Polonya Cumhurbaşkanı Lech Walesa, V4 oluşumunun sinırlı kurumsallaşmasının yararlı olacağını belirtmiştir. Daha sonra Mayıs ayındaki Prag Zirvesi'nde Cumhurbaşkanı Walesa, Çekoslovak ve Macar ortaklarıyla görüşerek, Vişegrad çerçevesinin, Avrupa Topluluğu'na paralel bir ekonomik ve siyasi entegrasyona dönüştürülmesini önermiş fakat diğer üyeler tarafından destek görmemiştir (Schmidt, 2016). İkinci ihtilaf ise 1993 yılında Çekoslavakya'nın dağılmasıyla birlikte asıl kurucu sayısının artmasıyla ortaya çıkmıştır. 1991'de Vişegrad Grubu'nu ayrı bir güvenlik sistemine dönüştürmek için yapılan Polonya girişimi, 1993 yılında tekrarlanmış ve yeni Çek Cumhuriyeti'nin ilk Cumhurbaşkanı olan Vaclav Havel, ülkesinin Vişegrad Grubu'nun rolünün değişmekte olduğuna inandığını açıkça belirtmiştir. Bir kurum olmak için çabalamak yerine, grubun üyeleri arasında somut işbirliği araçlarının önerilebileceği ekonomik ve politik bir danışma formuna dönüştürülmesi gerekliliğini vurgulanmıştır (Stepanovsky, 1995). Çek Cumhuriyeti'nin ilk Başbakanı Vaclav Klaus ise ülkesinin hedeflerinin Grubun ortak çıkarlarının yerini alacağını açıklamıştır. Başbakan Klaus, Çek Cumhuriyeti'nin Vişegrad işbirliğine daha fazla ilgi göstermeyeceğini belirterek, bunun yerine ana odak noktasının Batı Avrupa ile işbirliği olacağını ifade etmiştir ((Schmidt, 2016). 2002 yılında Budapeşte'de yapılması planlanan bir Vişegrad zirvesi öncesinde bir başka kriz patlak vermiştir. Zirvenin önde gelen gündem maddelerini $\mathrm{AB}^{\prime}$ ye katılım sürecindeki ülkeler için tarım ve bölgesel sübvansiyon önerileri gibi önemli hususlar oluşturmasına rağmen Çek Cumhuriyeti ve Slovakya, Macaristan Başbakanı Victor Orbán'ın “Beneş kararnamesinin AB üyeliğiyle bağdaşmadığı" (Naegele,2002) sözlerini protesto etmek için toplantıya katılmamıştır. Bu olaylar pek çok politikacı ve gazeteci tarafından "visegrad'ın klinik ölümü" (the clinical death of Visegrad) ya da "Orta Avrupa'nin sonu" (the end of Central Europe) şeklinde yorumlar yapılmasına neden olmuştur (Dangerfield, 2008). 
V4 ülkelerinin bölge üzerindeki kişisel çıarlarına yoğun odağını geçersiz kılabilecek herhangi bir bölgesel iç kimliğin veya ortak bölgesel çıkarın olmaması, yukarıda bahsedilen krizlerin sık sık tekrarlanmasına yol açmaktadır. Bu komplikasyonların bir başka nedeni olarak ise Polonya'nın V4'teki ülke büyüklügüne ve çok yönlü politikalarına dayanan baskınlığı gösterilmiştir. Ayrıca bölgedeki V4'ün "çekirdek" (core) pozisyonuna karşı Orta ve Doğu Avrupa'da "çevre" (peripheral) statüsünü hiçbir şekilde kabul etmeyen bazı dış aktörlerin -Avusturya, Hırvatistan ve Slovenya- yeni ve/veya paralel bölgesel entegrasyon faaliyetlerinin başlatılmasının arkasındaki faktörlerden olabileceği de belirtilmektedir (Cabada, 2018). Sık sık tekrar eden krizlerden ve çeşitli faktörlerden -Çek Cumhuriyeti'ndeki Klaus hükümetleri, Slovakya'nın Mečiarism dönemi, Macaristan Başbakanı Orbán'ın politikaları ve Polonya'nın sert güvenlik konusuna odağının artması- kaynaklanan iç uyum kaybına rağmen Vişegrad Grubu, Orta ve Doğu Avrupa işbirliği formatının en belirgin ve başarılı bir şekilde kalmasına devam etmiştir (Cabada, 2018).

Özellikle 2009 ile 2011 yılları arasında Vişegrad Grubu, AB ile ilgili kilit konularda ve birçok somut alanda işbirliği adına pratik ve faydalı sonuçları olan yepyeni bir dinamizm kazanmıştır. 2009 gaz krizi ve daha sonrasında enerji koordinasyonunun gelişimi; Grubun AB finansmanını ve $A B$ Komisyonu'nun ara bağlantı ve diğer eksik altyapıları inşa etmek için düzenleyici çerçevesini kullanmasına ve aynı zamanda gaz tedarikçiliği tekelinde olan Rusya'nın Gazprom şirketine meydan okumasına yardımcı olmuştur (Nic, 2016). Ayrıca V4 ülkelerinin $\mathrm{AB}^{\prime}$ ye katılımları öncesi dönemdeki yoğun iletişim nedeniyle, siyasi temsilciler ile diplomatik ve bürokratik aktörler arasında sağlam bir iletişim ağ1 kurulmuştur. Bu yoğun etkileşim ağı, sosyalizasyonu ve V4 işbirliğinin koşullarını daha da iyileştiren yarı-Vişegrad kimliğinin oluşumuna katkı sağlamıştır. Çok önemli bir başka değişim ise Vişegrad Grubu liderlerinin söylemlerinde görülmektedir. Geleneksel olarak AB içindeki oldukça dar bölgesel çıkarlara ve teşviklere odaklı V4 anlayışının ve söylemlerinin yerini tüm AB'ye enerji vermek ve yönlendirebilmek adına alt bölge işbirliğini ilerletmeye çalışan 'iyi Avrupalı' V4 seçkinleri almıştır. "Orta Avrupalılığın" siyasi anlayışı ve amacı, doğal bir "merkez" olarak hizmet veren ve kendilerini "Orta Avrupalılar" olarak 
nitelendiren diğer ülkeler için referans noktası olan Vişegrad alt bölgesel işbirliğine paralel olarak giderek artmıştır (Koran, 2010). Dahası Vişegrad Grubu siyasi işbirliği, V4 ülkeleri ile $A B$ sınırları dışındaki belirli Doğu komşuları arasında diyalog adına ek bir forum sağlamıştır. Örneğin; Vişegrad Grubu ile Belarus, Moldova ve Ukrayna yetkilileri arasındaki toplantılar, Vişegrad zirvelerinde ya da bakanların düzenli katıldıkları toplantılarda ayrı etkinlikler olarak özel oturumlar şeklinde gerçekleştirilmektedir (Dangerfield, 2009). Ayrıca AB'nin Doğu komşularında belirli bir reform yönünü destekleyerek çalışacak bir diş politika oyuncusu olarak Vişegrad işbirliğini geliştirmesi ve teşvik etmesi, V4'ün dış politika yapımındaki Avrupalılaşmasını net şekilde yansitmaktadır (Dangerfield, 2009). Ek olarak V4'ün AB gündemindeki işbirliği, Çek Cumhuriyeti (2009), Macaristan (2011) ve Polonya (2011) $\mathrm{AB}$ dönem başkanlıkları deneyimleriyle güçlendirilmiştir. V4 ülkeleri zaman içerisinde uyum, tek pazar, enerji, genişleme, Doğu Ortaklığı ve diğer $\mathrm{AB}$ politika alanlarındaki politika alıcılarından ziyade politika şekillendirici olmaya başlamıştır (Nic, 2016). AB içerisindeki artan tecrübeleri ve gelişimleriyle birlikte artık politika şekillendirici olmaya başlayan Vişegrad Grubu'nun krizler karşısındaki iç esnekliği de genişlemiştir. Örneğin; 2014 yılındaki Ukrayna krizinin başlangıcında yaşanan Grup içi derin bölünmelerle söz konusu bu durum sınırlarına kadar test edilmiştir. Öyle ki; Polonya'nın güçlü Rusya karşıtı duruşuyla Macaristan'ın Moskova'yla ayrıcalıklı ortaklığı arasında konumlanan Çekler ve Slovaklar, V4 içerisindeki artan iç esnekliği ve dayanıklılı̆̆ı her türlü fikir ayrılığına rağmen çok net şekilde gözler önüne sermiştir (Nic, 2016). Diğer taraftan V4 ülkeleri arasındaki fikir ayrilıklarından kaynaklanan sorunlar ile $\mathrm{V} 4-\mathrm{AB}$ arasındaki tercih farklılıklarından kaynaklanan sorunlar arasında da değişkenlikler gözlenmektedir. V4 ülkelerinin üzerinde fikir birliğine vararak karar verebildikleri tek sorun olarak göç ve mülteci krizi dikkat çekmektedir. Avro bölgesi, Lizbon Antlaşması, Brexit süreci gibi diğer sorunlara yönelik fikir ayrılıklarının sergilendiği tespit edilmiştir.

Bir krizle karşılaştırıldığında AB'nin yaşamış olduğu en sık görülen işbirliği sorunu dağıtımla ilgilidir. Her üye devlet, olabildiğince az katkıda bulunarak kolektif eylemden faydalanmak istemektedir. Bu tarz durumlar, krizle yüzleşmenin finansal veya başka bir yardım 
gerektirdiği koşullarda daha büyük sorunlar yaratmaktadır. AB'nin bugüne kadarki en tehlikeli işbirliği sorunlarının başında ise toplu karar verildikten sonrasında kriz çözümü için eylem akışının nasıl uygulanacağ 1 hususu olmuştur. Uygulamadaki sorun, bir üye devletin, işbirliğinin istenmesi halinde dahi farklı tercihlerde bulunması durumlarında ortaya çıkmaktadır (Kaili, 2016). AB, göçmenlerin Avrupa topraklarına akışını sağlamak ve durumu iyileştirmek amacıyla kolektif olarak bir eylem süreci üzerinde anlaşmaya varmış olsa da, Vişegrad Grubu'nun tepkileri özellikle dikkat çekicidir. Mülteci krizi, güneydoğudan artan göçmen tehdidine karşı eşgüdümlü bir reaksiyon gerektirdiğinden Vişegrad Grubu'nun kendi iç esnekliği kapsamındaki fikir ayrilıklarından sıyrılarak yeniden doğmasına neden olmuştur. Aynı zamanda, 2015 yılında Macaristan dışında, bölge krizden etkilenmemiş ve sığınmacıların ve tanınmış mültecilerin sayısı oldukça düşük kalmıştır (Frelak, 2017). Bunun üzerine Macaristan Başbakanı, ulusal çıkarlara öncelik veren ilk kişi olmuş ve sonrasında bu bakış açısı, diğer üç üye devlet tarafından da benimsenmiştir. Şubat 2016'da devletler tarafından ortak güvenlik politikasına dair endişeler dile getirilmiş ve Romanya, Bulgaristan ve Makedonya ile daha yakın işbirliği geliştirilmesi gerekliliği ve mültecilerin Yunanistan sınırında durdurulmasına dair planlara yönelik ortak bir açıklama yapılmıştır (Schmidt, 2016). Zirve neticesinde yapılan açıklamalarda "dış sınırların daha etkin korunması amaciyla $\mathrm{AB}$ düzeyinde alınan önlemlere tam destek" olunduğu belirtilmiştir. Ancak liderler ayrıca göçmenlerin Türkiye'den ayrılmalarını engelleme çabalarının yetersiz kalması durumunda "alternatif bir yedek planın (back-up plan)" oluşturulması talebinde bulunmuşlardır. Orta Avrupa ülkeleri, AB'nin mülteci programındaki yeniden yerleştirme kotalarının tekrardan düzenlenmesi teşebbüslerine genel olarak karşı gelmişlerdir. Hatta Macaristan lideri, "ikinci bir savunma hattı" oluşturulmasını desteklemeye hazır olduklarını belirtmiştir (Cienski, 2016, www.politico.eu). Sınır güvenliğinin güçlendirilmesi adına alınacak her türlü önlem sayesinde $\mathrm{AB}^{\prime}$ nin temellerinin sorgulandığ $\mathrm{AB}$ içinde yeni bir krizin oluşması riskinin azalacağ belirtilmiştir (Foy, 2016, www.ft.com). V4'ün gelişimi ve merkezi kurumlar tarafından temsil edilen siyasi bir kurum olarak $A B$ ile ilişkileri, göç kriziyle birlikte keskin şekilde ayrılmış ve Avrupa 
entegrasyon sürecinde uzun zamandır var olan fikir birliği mekanizmalarının ve uyumun bozucusu şeklinde V4'ün imajı öne çıkarılmıştır. V4 ülkeleri söz konusu göç krizini ciddi bir güvenlik sorunu olarak görmüşler ve hızla güvenlikleştirerek V4'teki birçok siyasi aktörün politik stratejilerini öncelikle göçün olumsuzlaştırılmasıyla bağlantılı bir korku politikasına evriltmişlerdir (Cabada ve Waisova, 2018). Vişegrad ülkelerinin bu politikası, ortak Avrupa politikasına darbe ve $A B^{\prime}$ nin ayrışmasının bir işareti olarak yorumlanmıştır (Ivanova, 2016).

AB Komisyonu ile birlikte Almanya, Fransa, İtalya ve Yunanistan gibi önde gelen ülkelerin "mülteci sorununun Avrupa toprakları içerisinde çözümü" önerilerine karşılık Vişegrad Grubu'nun yaklaşımı, daha geniş perspektifli ve uzun vadeli olmuştur. Dış eylem planlarının öncelendiği bu bakış açısında, "önemli miktarda mülteci nüfusu olan ülkelere (Türkiye, Ürdün, Irak, Lübnan ve Batı Balkanların transit ülkeleri de dâhil olmak üzere) mali yardım sağlamaya hazır olunduğu" belirtilmiştir. Ayrıca $\mathrm{AB}^{\prime}$ nin dış sınırlarını korumak ve iltica prosedürlerini etkili şekilde yönetebilmek için "uzman ve teknik donanım hizmeti" sağlayabilecekleri de eklenmiştir (Maurice, 2015, euobserver.com). Bu bağlamda üye devletler arasında, sığınmacıların kotasının yeniden dağıtılmasına odaklanılma çabaları etkisiz bulunmakta, bunun yerine göç akışının ana dalgasının yerleri olan Suriye ve Irak'taki çatışmaların politik çözümüne ve bu bölgedeki tüm terör örgütleriyle etkin mücadeleye ağırlık verilmesi gerektiğine inanılmaktadır (Ivanova 2016). Grubun bu tavrı, aşırı milliyetçi bir yaklaşım ve yabancı düşmanlı̆̆ı şeklinde yorumlansa da aslında uluslarüstü (supranasyonel) baskı yoluyla başka bir tutum dayatmanın işe yaramadığının ya da amaca zarar verici şekilde reaksiyon doğurduğunun en net göstergesi olmuştur (Wahl, 2017). Ayrıca AB'nin mülteci kriziyle alakalı olarak Orta Avrupa ülkeleri ile doğrudan istişarelerde bulunmaması, "eski $A B$ "nin "yeni üyeleri"ni görmezden geldiğine dair söylemlerin güç kazanmasına neden olmuştur (Schöpflin, 2016, www.aspenreview.com). Bu nedenle Orta Avrupa'daki mültecilere yönelik politik kararların arkasındaki faktörlerin ve sert tepkilerin anlaşılması son derece önemlidir (Frelak, 2017). 
Son olarak söz konusu mülteci ve göç krizi, bazı Orta Avrupa ülkelerinde -özellikle Macaristan ve Polonya' da- AB ile ilişkilerde daha iddialı bir tezahür şekli için bahane oluşturmuştur. Ayrıca bu dönemde muhafazakâr partilerin anti-liberal programlarla iktidara gelmeleri neticesinde iç siyasi değişimler de yaşanmıştır. Viktor Orbán ve Jarosław Kaczyński gibi liderler, V4'e kendi radikal, milliyetçi-muhafazakâr ideoloji ve politikalarının birer aracı şeklinde yaklaşım sergilemişlerdir. $\mathrm{Bu}$ durum da, liberal Batı'ya ve kurumlarına karşı olan yaygın ters tepkiyi tetiklemiştir (Jasiecki, 2016).

Öte taraftan V4 ülkelerin 2004 yılında $\mathrm{AB}^{\prime}$ ye tam üye oldukları beşinci büyüme dalgasıyla $\mathrm{AB}^{\prime}$ nin artan üye sayısı, Birliğin kurumsal yapısı ve karar alma mekanizmaları üzerinde reform ihtiyacinı doğurmuştur. Uzun yıllar süren zorlu müzakereler, üzerinde mutabakata varılmıs $\mathrm{AB}$ Anayasal Antlaşması'nın Fransa ve Hollanda referandumlarında reddedilmelerinin ardından kurumsal işleyiş ve politika konuları ağırlıklı olarak revize edilmiş ve Lizbon Antlaşması 13 Aralık 2007 tarihindeki AB Zirvesinde üye ülke liderleri tarafından imzalanarak 1 Aralı 2009 tarihinde yürürlüğe girmiştir (LizbonAntlaşması, t.y., www.mfa.gov.tr). Buna göre Lizbon Antlaşması sonrasında $\mathrm{AB}$, karakter bakımından daha ulus-üstü bir nitelik kazanmıştır. Birliğin yenilenen antlaşma çerçevesi, nitelikli çoğunluk oylaması (qualified majority voting, QMV) yönteminin kullanıldığı konu ve politika alanlarını önemli ölçüde genişletmiştir. Karar almanın niteliği ve doğası, Avrupa siyasetinin ulus-üstü kurumlarının artan rolü yönünde önemli ölçüde değiştirilmiş ve kaydırılmıştır. Nitelikli çoğunluk oylamasıyla karar almanın kapsamına paralel olarak, Avrupa Parlamentosu'nun (AP) rolü de belirleyici şekilde genişletilmiştir. Konsey ve AP arasındaki yasa yapma sürecinde ortak karar alınması, yeniden tasarlanan yeterliliklerin ve kurumsal yetkilerin paylaştırılması altında yaygın bir mevzuat formu haline gelmiştir (Törö vd., 2014).

Lizbon Antlaşması, pek çok hususta $A B$ üyesi ülkeler tarafından tartışılmış ve eleştirilmiş olmasının yanı sıra Vişegrad Grubu ülkeleri açısından da önemli birtakım zorluklar ortaya çıarmıştır. Konsey tarafından kabul edilme eşiğini düşüren yeni çoğunluk oylama kuralları, V4'ün engelleyici bir azınlık yaratma potansiyelini kaybettirmiştir. 2015 yılı, göç ve mülteci kriziyle birlikte $V 4$ 'ü öne çıkaran bir yıl olarak 
algılanmış olsa da, V4'ün oylama bloğu olarak kabul edilmesi oldukça geç kalmıştır. Eski oylama kurallarına göre V4 ülkeleri, büyük üyelerden Fransa ve Almanya ile karşılaştırıldığında, nominal olarak eşit miktarda oy hakkına sahipken (58 oy), yenilenmiş nitelikli çoğunluk oylaması sistemiyle V4'ün ağırlığı düşmüştür. Eskiden V4 ülkeleri açısından Almanya, Fransa, İngiltere, İtalya veya İspanya gibi büyük üye devletlerden birinin (27 ila 29 oy) ve diğer bir küçük üye devletin (14 ila 7 oy arasında değişen) desteğiyle engelleyici bir azınlığın (Konsey'deki 352 oydan 93'e karşılık gelmektedir) yaratılması mümkünken, yeni kurallara göre engelleyici bir azınlık bloğu için $\mathrm{AB}$ nüfusunun \%35'inden fazlasını temsil eden en az dört Konsey üyesi gerekmektedir. Bu durum ise şüphesiz büyük üye devletlere daha fazla ağırlık vermektedir. V4 ülkeleri, $\mathrm{AB}$ nüfusunun yalnızca \%13'ünü oluşturmaktadır. $\mathrm{Bu}$ oran, engelleyici bir azınlık oluşturmak için en az bir büyük üye devlete ve çok sayıda küçük üye devlete ihtiyaç olduğunu göstermekte ve böylece müzakere kaldıracının arttığı görülmektedir (Luining, 2017). Yaşanan bu değişim, Vişegrad Grubu'ndaki merkezkaç eğilimini güçlendirebileceği gibi aksine diğer $\mathrm{AB}$ üyeleri ya da bölgesel girişimlerle geçici koalisyonlar kurma konusunda da bir teşvik olabileceği şeklindeki yorumları beraberinde getirmiştir. Ancak bu durum, AB düzeyinde daha fazla ortak çekebilmek adına V4 ülkelerinin olumlu bir gündemde yoğunlaşması gerekliliğini de elzem kılmaktadır. Bu bağlamda Avrupa entegrasyonunun olası derinleşmesi, zorunlu ve daha güçlü bir kurumsal yapı bulunmasa da, V4 ülkeleriyle işbirliğinin daha da geliştirilmesini gerektirecektir. Dolayısıyla mevcut işbirliği araçlarının daha yoğun kullanılmasının yanı sıra yeni önlemlerin alınması gibi diğer olasılıkların da göz önünde bulundurulması gerekmektedir (Stráǎay, 2018). Bu değişikliklerin Vişegrad ülkeleri tarafından iki önemli çıkarımı dikkate alınmalıdır: Birincisi, AB kurumsal çerçevesi içindeki Vişegrad ülkeleri arasında işbirliği için siyasi ortam değişmiştir. Eğer V4, politika oluşumunun ve karar vermenin nihai sonuçları üzerinde belirgin bir etki yapmak istiyorsa söz konusu durumu dikkate almalıdır. İkinci olarak ise yenilenmiş nitelikli çoğunluğa dayalı oylamayla daha fazla karar alınacağının ortaya çıkması, oybirliği kuralıyla alınan kararların olumsuz sonuçları karşısındaki ülkelere korunma alanı açısından daha az yer bırakmaktadır. Tabiatıyla kabul edilebilir uzlaşılar ya da yeterince 
zorlayıcı koalisyonlar sağlanamadıkça, üye devletler için "politika savaşlarının" kaybedilen taraflarında azınlık pozisyonuna düşme olasılığını arttırmaktadır (Törö vd., 2014).

V4-AB ilişkilerinde sorun yaratan gelişmelerden biri de Lizbon Antlaşması'na dâhil olarak ortaya konan AB Temel Haklar Şartı Protokolü'ne kısaca temas etmekte fayda bulunmaktadır. Söz konusu Protokol, üye devletlerin kendi iç hukuk hükümlerinin, $A B$ hukukuna aykırı olması sebebiyle uygulanmaması ve değiştirilmesi endişesine dayanmaktadır. Polonya bu antlaşmaya bağlı olarak ortaya konan AB Temel Haklar Şartının bağlayıcı olması nedeniyle uygulama alanını sınırlamaya çalışmıştır. Sınırlama getirmesinin en temel nedenleri arasında sosyal haklar ve işgücü haklarından ziyade ülkedeki dindarlığın yoğun olması gelmektedir. Özgürlük alanlarının arttırıldığı bu Antlaşma ile Polonya, eşcinsel evlilikleri tanımak istememiş ve kürtaj serbestliğinin ülkesine zarar vereceğini düşünmüştür. Bu nedenle uzun süre imzalamadığı bu Antlaşma sonrasında $A B$, Polonya ve İngiltere'ye çekindikleri konularda opt out (dışında kalma) hakkı tanıyarak bu maddelerin olmadığı Temel Haklar Protokolü'nü imzalatmıştır (Metin ve Kaygisız, 2011). Lizbon Antlaşması'nda sorun yaşanmasına neden olan bir diğer V4 ülkesi ise Çek Cumhuriyeti olmuştur. Çek Cumhuriyeti, AB Temel Haklar Şartı Protokolü'nün II. Dünya Savaşı sonrasında yerlerinden edilen Almanlara eski mülklerini talep etme hakkı tanıyacağı korkusuyla Lizbon Antlaşması'nı geç imzalamıştır (Avrupa Birliği Çek Cumhuriyeti'ne Boyun Eğdi, 2009, www.amerikaninsesi.com). Dolayısıyla bu tarz istisnai düzenlemeler, $\mathrm{AB}$ temel haklarının korunmasında bütünleşmeyi engellediği endişelerini ortaya çıkarmış; ancak Temel Haklar Şartı'nın yargısal açıdan geçerli kılınmasına sinırlama getirilmesiyle kısmen giderilmiştir (Metin ve Kaygisız, 2011).

V4 ülkelerinin AB ile ilgili sıkıntılı olduğu bir başka husus ise Avro bölgesiyle alakalıdır. 2009 yılında Avro bölgesi krizi gerçekleştiğinde, Ekonomik ve Parasal Birlik'in (Economic and Monetary Union, EMU) yaptığı düzenlemelerin, aynı kurallar sistemine bağlı devletlerden kimilerini diğerlerine kıyasla daha iyi hale getirdiği ve adil olmadığ anlaşılmıştır. Kazan-kazan özelliğinden ziyade dengesiz dağıtıcı etkilere sahip olan bu düzenlemeler kapsamında Avro Bölgesi'nin tasarımı ve 
kriz yönetimi, kazananlar ve kaybedenler yaratmıştır. Avro bölgesi krizi, yapısal adaletsizlik sorununu gündeme taşımış ve yaşanan çeşitli adaletsizlikler, bazı aktörlerin Avro bölgesine doğrudan ya da dolaylı olarak katılmasına neden olurken, bazılarının ise katılmamayı tercih etmesine neden olmuştur (Eriksen, 2017).

V4 ülkeleri arasında şu ana kadar sadece Slovakya Avro bölgesine katılmış, diğer üçü ise henüz Avro'ya geçiş sağlamamıştır. 1992 tarihli Maastricht Antlaşması'na göre Avro'ya geçiş yapmayan ülkelerin gerekli şartları bir an önce tamamlamaya çalışmaları ve hazır olduklarında Avro'ya geçiş yapmaları gerekmektedir (What is the Euro area, t.y., ec.europa.eu). Macaristan, Avro bölgesine katılmanın ülkenin ekonomik kalkınması üzerinde olumsuz etki edeceği ve ekonomi politikasının esnekliğini kaybedeceği gibi konularda endişeler taşımaktadır. Bu nedenle ortak para birimini etkileyen süreçler hakkında daha fazla bilgi edinilmesi gerekliliği vurgulanarak Avro'ya geçiş konusunda kesin bir zaman çizelgesi olmadığı açıkça belirtilmektedir (Sarnyai, 2019, hungarytoday.hu). Çek Cumhuriyeti'ne bakıldığında ise eski Başbakan Bohuslav Sobotka döneminde 2020 yılına kadar Avro'ya geçiş hedefleri tartışmaya açılmış (Muller, 2015, www.euractiv.com), 2017 yılında iktidara gelen mevcut Başbakan Andrej Babiš tarafından ise açıkça Avro'ya geçişin ülkesi adına uygun olmadığı, olası geçişin ülkesini ekonomik şoklar karşısında dirençsiz bırakacağı ve hatta Yunanistan ile İtalya'nın da Avro bölgesinden çıkması gerektiği belirtilmiştir (Dawkins, 2019, www.forbes.com). Son olarak Polonya'ya bakıldığında, 2014'ün sonlarında Ewa Kopacz başkanlığındaki kısa ömürlü hükümet, Polonya'nın Avro bölgesine girişini hızlandırmaya çalışmış ancak Avro'nun kabul edilmesi için makul bir plan üzerinde anlaşılamamıştır (Tianping, 2017). Sonrasında gelen hükümetlerde ise Avro'ya karşı şüpheci yaklaşım daha yoğun olmuştur. Şu anki mevcut Başbakan Mateusz Morawiecki Avro'ya geçişin Polonya'nın yararına olmadığını şu örnekle ifade etmiştir: "2007 yılında Yunan ekonomisi Almanya'dan 10 kat daha küçükken, 2019 yılında bu fark 18 kata çıkmıştır (Shah, 2019, emergingeurope.com)."

Ayrıca son olarak Brexit sürecine yönelik V4 ülkelerinin yaklaşımlarına kısaca değinilmesinde fayda görülmektedir; çünkü süreç açısından İngiltere'nin AB'den ayrılma kararı, V4'ün siyasi uyumu için 
önemli sonuçlar yaratmıştır. Göç krizi durulmaya başlamışken, 23 Haziran 2016 tarihinde İngiltere'de gerçekleştirilen Brexit oylaması, $A B^{\prime}$ nin reform tartışmalarını yeniden canlandırmış ve $V 4$ 'ün ulusal görüşleri arasında kaynayan bölünmelerini tekrardan ortaya çıkarmıştır (Nic, 2016). V4 ülkeleri, Brexit sürecinin Avrupa içindeki dengeleri değiştireceğinden ve güç dağglımını farklı boyutlara götüreceğinden büyük kaygı duymuşlardır. AB içerisindeki reform tartışmalarının da yeniden canlanmasıyla olası yeni entegrasyon modellerinden dışlanılma ya da Brexit sonrası oluşan yeni $A B$ formasyonunda büyük ülkelerin çıkarları uğruna kendi çıkarlarının zarara uğratılması gibi endişeler giderek artmıştır (Hekimler, 2017). Dahası Brexit süreciyle genel perspektiften $\mathrm{AB}$ içi işbirliği, spesifik olarak ise bölgesel Orta Avrupa işbirliği açısından iki önemli belirsizlik yaratılmıştır. Gelecekteki ABİngiltere ilişkilerinin nasıl şekilleneceği, $\mathrm{AB}$ ortak pazarının korunması konusu vb durumlar İngiltere ve V4 ülkeleri arasında bazı ortak zeminler bulabilecekleri bir alan yaratabilir. Buna karşıllk Brexit sonrası $\mathrm{V} 4$ ülkelerinin $\mathrm{AB}^{\prime}$ ye karşı ortak duruşunun nasıl olacağı ise asıl soru işaretini oluşturmaktadır. Slovakya'nın Avro bölgesinde yer aldığg, Çekya'nın Alman ekonomisiyle olan yakın ilişkisi, Macaristan ve Polonya'nın ise $\mathrm{AB}^{\prime}$ ye karşı olan kuşkucu ve sınırlı yaklaşımı göz önünde bulundurulduğunda, Orta Avrupa bölgesindeki işbirliğinin çok daha sorunlu bir hal alabileceği öngörülebilmektedir (Bilcik, 2017). Diğer taraftan tüm üye ülkeleri ilgilendiren ama özellikle Polonya' yı daha fazla ilgilendiren diğer bir husus, İngiltere'nin $A B^{\prime}$ den çımasıyla $A B^{\prime}$ nin büyüklüğünde yaşanacak değişimin oy kullanma gücüne yapacağ1 etkiyle alakalıdır. İngiltere'nin ayrılışı, diğer üye ülkelerin nüfuslarının Birliğin toplam popülasyonundaki artan oranı nedeniyle oy kullanma gücünü otomatik olarak değiştirmektedir. Bu değişim özellikle Almanya, Fransa, İtalya, İspanya ve Polonya açısından çok daha olumlu yansıyacaktır. Göreceli olarak nüfusa göre oy oranları ülkelere dağıtıldığında oy gücüne etkisi en fazla olan ülke Polonya (\%27.8) olmakta, İspanya (\%23) ise onu takip etmektedir. Diğer V4 ülkeleri Çekya (\%4), Macaristan (\%3.6) ve Slovakya (\%0.7)- ise çok daha düşük kazanımlar elde etmektedirler (Göllner, 2017). Bu durumun Polonya'nın $A B^{\prime}$ ye karşı olan kuşkucu ve sınırlı tavrına nasıl etki edeceği ise merak konusudur. 
Netice olarak Vişegrad Grubu ülkelerinin hem Orta ve Doğu Avrupa bölgesindeki işbirliği hem de $A B$ ile olan etkileşimi çok yönlü, çeşitli faydaları ve sorunları bir arada barındırmaktadır. V4 ülkeleri, güçlü, istikrarlı ve demokratik bir Avrupa'ya katkıda bulunmayı amaçlayan ve küresel arenadaki barış ve sürdürülebilir kalkınmanın içindeki konumunu güçlendirmeyi hedefleyen karşıllklı işbirliğini sürdürme ve daha da geliştirme kararlılıklarını teyit etmektedir. Yaşanan ve yaşanabilecek ekonomik, finansal ve siyasi krizleri çözmek için rekabet edilebilirliği artıracak ve V4 ile AB'nin küresel düzeyde uyumunu ilerletecek projeler yürüterek Avrupa'nın güçlenmesinde aktif olarak yer almaktadırlar (Szilágyi, 2014). Ancak V4 ülkeleri, sadece mülteci ve göç kriziyle ilgili sorunlar üzerinde homojen bir pozisyon yaratabilmişlerdir. Bunun dişında $A B^{\prime}$ nin geleceği, Avro bölgesi, Brexit süreci, Brexit sonrası Almanya ve Fransa'nun yeni $A B$ formasyonundaki rolü, enerji sorunları ve Rusya gibi aktörlere uygulanacak yaptırımlar gibi pek çok konuda ise konumları dağınık kalmaktadır (Bil, 2017). Tüm bunlara rağmen Vişegrad Grubu, sahip olduğu işbirliği formatıyla ve niteliğiyle gerek bölge dinamikleri gerekse $A B$ işleyişi açısından hala denge unsuru olmaya devam etmektedir.

\section{Sonuç ve Tartışma}

Orta ve Doğu Avrupa, tarihsel olarak her daim sorunlu bir coğrafya olmuştur. Ekonomik, kültürel, etnik ve politik dezavantajlardan dolayı bölge içerisinde efektif ve istikrarlı işbirliği oluşturma çabaları genellikle başarısızlıkla sonuçlanmıştır. Bu bağlamda "Vişegrad Grubu" olarak adlandırılan dörtlü organizasyon, bölgedeki en başarılı işbirliği olarak halen faal olarak çalışmaktadır. AB ve NATO üyesi olan Vişegrad ülkeleri, hem $\mathrm{AB}^{\prime}$ ye hem de bölge istikrarına müspet faydalar sağlamaktadır. $\mathrm{AB}^{\prime}$ nin Doğu Avrupa ile ilişkilerinin geliştirilmesi, sınırsız ekonomik ve sınırlı siyasi işbirliklerinin arttırılması ve $A B^{\prime}$ nin Doğu sınırlarının güvenliği gibi hususlarda Vişegrad Grubu'nun son derece önemli katkılarda bulunduğu görülmektedir. Öte yandan Grubun hem kendi içerisinde hem de AB ile olan ilişkilerinde çeşitli sıkıntıların yaşandığ 1 da tespit edilmiştir. Vişegrad Grubu'nun kurumsal kimliğine ve kendi sınırları içerisindeki diğer Grup üyelerinin etnik azınlıklarına 
yönelik politika uygulamalarında müşterek payda oluşturulamamıştır. (EVET DEĞİNILLİ) Ancak Vişegrad işbirliği sayesinde, fikir ayrılıkları asgari seviyelerde tutulmakta ve üyelerin tarihsel olarak yapmış oldukları hataların -kendi ulusal çıarlarına doğrudan zarar verebilecek boyutlara ulaşmak- tekrarına imkân verilmemektedir. Diğer taraftan ise hem doğrudan $A B^{\prime}$ ye yönelik hem de $A B^{\prime}$ nin karşılaştı̆̆ sorunlara karşı uyguladığ1 politika tercihlerine yönelik Vişegrad ülkeleri ile $\mathrm{AB}$ arasında problemler yaşanmaktadır. Mülteci sorunu ve göç krizi, V4 ülkelerinin duruşları açısından fikir birliğine varabildiği tek sorun olarak dikkat çekmektedir. Brexit süreci, Avro bölgesi, yargı reformları ve özgürlüklerle alakalı konularda Vişegrad Grubu'nun fikir ayrılıkları belirgin boyutlara ulaşmıştır. Bu tarz sorunlu hususlarda V4 ülkeleri AB’ye karşı Rusya Federasyonu faktörünü denge unsuru olarak kullanmayı tercih etmektedir. Rusya Federasyonu'nun V4 ülkeleri üzerindeki tarihsel etkileri, bu coğrafyanın Batı ile entegrasyonu sayesinde kırılmıştır. Ancak Batı'nın Vişegrad ülkelerine karşı "Eski Avrupa" yaklaşımının zaman zaman nüksetmesi, V4 ülkelerinin azami çıkarlar etrafında ortak hareket edebilmesine neden olmaktadır. Netice olarak Vişegrad Grubu, AB ile siyasi sorunlara rağmen, ekonomik anlamda işbirliğinin ve istikrarın sembolü olmaya devam etmektedir. 


\title{
EXTENDED ABSTRACT
}

\section{An Analysis on Visegrad Group: Formation, Functioning, Effects and Problems}

\author{
Selim Yeşiltaş- Tolga Erdem \\ Sakarya University-Trakya University
}

The Visegrad Group is a Central and Eastern European co-operation organization, which dates back to 1991, although its origins are longestablished. In this study, the formation, operation, effects and problems experienced by the Visegrad Group from past to present are analyzed in a multidimensional way. In addition, the integration process of Visegrad countries to the West and the issues they face during this process are discussed in detail. The main purpose of the group was to get rid of the influence of communism and to fully adapt to the West, militarily and economically. However, it is seen that Visegrad countries are also involved in the problems of harmonization within Europe after full membership to the EU. The refugee issue and migration crisis in 2014, and beginning of the Brexit process in 2016, has caused the Visegrad Group to become a full opposition character within the EU. On the other hand, as the group felt excluded from the EU, its problems with the EU tended to increase continuously. In this context, the problems in the relations between the two sides and the reason why these problems cannot be solved despite the dialogue approach of the European Union constitute the main analysis scope of this study.

The countries of Poland, Hungary, Czechia and Slovakia, which are referred to as the "Visegrad Group", have been experiencing serious tensions with the European Union (EU). However, harmonization with the EU and becoming a full member came first among the common targets set by the Group in 1991. Established in this direction, the Group even pacified the Group in order to accelerate individual harmonization with the EU when necessary. However, on the other hand, Visegrad countries have mostly been an obstacle to the integration efforts of the Union after becoming a member of the Union in 2004. Members who use their opt-out rights in treaties for various reasons have been kept in the 
EU's integration process, generally through dialogue. However, the process of resolving the negative developments through dialogue, which lasted until 2014, brought along problems that could not be avoided with the refugee crisis. Since this date, the Visegrad Four (V4) countries have entered the most problematic period with the EU. The increase in refugee flow to Europe with the Arab Spring caused unavoidable problems in Europe and V4 members did not hesitate to stand against countries such as Germany and France, which are the great powers of the EU. The members, who did not accept the impositions imposed on them with the "compulsory refugee quota application", which means the dispersal of refugees within the EU, received support from the opposition groups of other countries in time, and they canceled the obligation of the quota application. However, Poland subsequently experienced a judicial reform crisis with the EU, and Hungary a media pressure crisis with the EU. These issues have brought to the agenda within the scope of Article 7 of the EU Basic Treaty - the exclusion of countries from the decision mechanism in case of opposition to freedom. Thereupon, the aforementioned countries made reference to the mandatory quota system and declared that the problem was political and the crisis deepened. On the other hand, with the Brexit referendum held in 2016, the V4 members faced the danger of losing the UK, which was a balancing power against the pro-European policy of Germany and France in the EU. This situation increased the feelings of exclusion of V4 members from the EU and increased solidarity within the group. Therefore, while the Group was experiencing its most problematic period with the EU, on the other hand, it started to experience its best period within itself. As the crisis deepened in general, V4 emerged as a new oppositional front within the EU. While V4 was accused of not complying with the integration moves by the EU; He accused the EU of destroying national identity.

The aim of this study is to determine the level of damage caused by the conflicts of Visegrad countries with the EU in the EU integration process. In this context, first of all, general information on the formation and functioning of the Visegrad Group will be presented, then the reflections of the Visegrad Group on the EU and Central and Eastern Europe will be examined, and finally on the Visegrad Group both within 
itself and in its relations with the EU. The benefits it provides and the problems it encounters will be detailed together. In addition, the attitudes of the parties in the problems experienced will be revealed, and determinations will be made about the future of the problems that arise.

\section{Kaynakça / References}

Amerika'nın Sesi (2009). Avrupa Birliği Çek Cumhuriyeti'ne Boyun Eğdi. 30 Ekim 2009, https://www.amerikaninsesi.com/a/a-17-2009-10-30-voa388154242/874138.html, (Erişim Tarihi: 13 Temmuz 2019).

Asmus, R. D., Kugler R. L and Larrabee, S. (1993). Building A New NATO. Foreign Affairs, 72(4), 28-40.

Balogova, B. (2009). Sharing what visegrad countries have learned. Visegrad Countries Special, The Slovak Spectator, s.1-8.

BBC NEWS (2016). Hungary PM claims EU migrant quota referandum victory. 03.10.2016, https://www.bbc.com/news/world-europe-37528325, (Erişim Tarihi: 10 Nisan 2019).

BBC TÜRKÇE (2019). Avrupa ve milliyetçilik: Avrupa parlamentosu seçimlerinde milliyetçi ve aşırı sağcı partiler 'güç bloğu' oluşturma çabasında. 20 Mayıs 2019, https://www.bbc.com/turkce/haberler-dunya45474089, (Erişim Tarihi: 20 Mart 2019).

Bialasiewicz, L. (2009). Europe as/at the border: Trieste and the meaning of Europe. Social \& Cultural Geography, 10(3), 319-336.

Bil, I. (2017). Lessons from 26 years of visegrad's history. The Future of The Visegrad Group içinde, Editörler: Ania Skrzypek \& Maria Skora, Foundation for European Progressive Studies, Das Progressive Zentrum, Brüksel/Berlin 2017, s.38-42.

Bilcik, V. (2017 Ocak). Council presidency and brexit: from unexpected calm to likely storm., Think Visegrad, V4 Think-Thank Platform, Policy Brief.

Buteux, P. (1995). Contructing a New Consensus. International Journal, The Future of NATO, 50(4), 730-737.

Cabada, L. (2018). The visegrad cooperation in the context of other central european cooperation formats. Politics in Central Europe, 14(2), 165-179.

Cabada, L. and Šarka W. (2018). The Visegrad Group as an ambitious actor of (Central-)European foreign and security policy. Politics in Central Europe, 14(2), 9-20. 
Ceeidentity National Idenities (2019). Direction-social democracy (Socialna Demokracia, Smer SD). http://www.ceeidentity.eu/database/manifestoescoun/direction, (Erişim Tarihi: 21 Mart 2019).

Cienski, J. (2019). Central Europe wants to halt migration If EU plan fails. Politico, 15 Şubat 2016, https://www.politico.eu/article/migrants-asylumorban-visegrad-poland-hungary-chezch-slovakia-migration-refugees/, (Erişim Tarihi: 7 Temmuz 2019).

Dangerfield, M. (2008). The Visegrad Group in the expanded European Union: from preaccession to postaccession cooperation. East European Politics and Societies, 22(3), 630-667.

Dangerfield, M. (2009). The contribution of the Visegrad Group to the European Union's 'Eastern' policy: Rhetoric or reality? Europe-Asia Studies, 61(1)0, 1735-1755.

Dawkins, D. (2019). Czech Prime Minister Babiš - 'Europe Is At A Crossroads', Forbes, https://www.forbes.com/sites/daviddawkins/2019/06/08/czech-primeminister-babieurope-is-at-a-crossroads/\#6c61910413db, (Erişimi Tarihi: 13 Temmuz 2019).

Deutsche Welle (2018). Visegrad Countries urge stronger EU border defense. 21.06.2018, https://www.dw.com/en/visegrad-countries-urge-stronger-euborder-defense/a-44336264-0, (Erişim Tarihi: 12 Nisan 2019).

Deutsche Welle (2017). Çek Seçimlerinin Galibi Açık Ara ile Babiş, 21.10.2017, https://www.dw.com/tr/\%C3\%A7ek-se\%C3\%A7imlerinin-galibia\%C3\%A7\%C4\%B1k-ara-farkla-babi\%C5\%9F/a-41062639, (Erişim Tarihi: 10 Haziran 2019).

Eriksen, E. O. (2017). Structural injustice: The Eurozone Crisis and the Duty of Solidarity. Solidarity in the European Union: A Fundamental Value in Crisis, Springer International Publishing $A G$, Editörler: Andreas Grimmel \& Susanne My Giang, s.97-118.

European Commission (2019). What is the Euro Area?, https://ec.europa.eu/info/business-economy-euro/euro-area/what-euroarea en, (Erişim Tarihi: 13 Temmuz 2019).

France Diplomatie (2019). Visegrad Group. https://www.diplomatie.gouv.fr/en/country-files/czech-republic/visegradgroup/, (Erişim Tarihi: 18 Temmuz 2019).

Frelak, J. S. (2017). Solidarity in European migration policy: The perspective of the Visegrad States. Solidarity in the European Union: A Fundamental 
Value in Crisis, Springer International Publishing AG, Editörler: Andreas Grimmel \& Susanne My Giang, s.81-95.

Foy, H. (2019). Central Europe States keep migrant heat on athens. Financial Times, 16 Şubat 2016. https://www.ft.com/content/c15b28f2-d425-11e58887-98e7feb46f27, (Erişim Tarihi: 7 Temmuz 2019).

Gollner, R. T. (2017). The Visegrád Group - a rising star post-brexit? Changing distribution of power in the European Council. Open Political Science, 1(1), 1-6.

Handl, V, Kerry L. and Marcin Z. (2000). Germany's security policy towards East Central Europe. Perspectives, 14, 54-70.

Hekimler, O. (2017). Brexit sonrasında merkezi ve orta avrupa'y1 yeniden düşünmek. Marmara Araştırmaları Dergisi, 25(1), 1-33.

Inotai, A. and Magdolna S. (1994). Economic integration of the Visegrad Countries: Facts and scenarios. Eastern European Economics, 32(6), 6-28.

Ivanova, D. (2016). Migrant crisis and the Visegrad Group's Policy. International Conference Knowledge-Based Organization, 22(1), 35-39.

Jasiecki, K. (2016). Economic cooperation among the Visegrad Countries. The Visegrad Countries in Crisis, Editör: Jan Pakulski. Collegium Civitas, Varşova 2016, s.160-121.

Kaili, E. (2016). Beyond Cooperation Failures: How European Crises Make the European Union Stronger. The Fletcher Forum of World Affairs, 40(2), 163-172.

Kegley, C. W. and Shannon L. B. (2015). Dünya siyaseti yönelim ve dönüşüm. Sakarya Üniversitesi Kültür Yayınları, 1. Basım, Sakarya, s.39-143.

Klein, R. (2019). This is how the Visegrad Group Works. Deutsche Welle, 07.02.2019, https://www.dw.com/en/this-is-how-the-visegrad-groupworks/a-47402724, (Erişim Tarihi: 12 Nisan 2019).

Kolankiewicz, G. (1994). Consensus and Competition in the eastern enlargement of the European Union. International Affairs (Royal Institue of International Affairs 1944-), 70(3), 477-495.

Kořan, M. (2010). Forum on 'Central Europe': Introduction. Perspectives, 18(2), 57-62.

Lázár, A. M. (2014). Post-EU-accession Visegrad Cooperation: Results, rhetoric, prospects. Biztpol Affairs, 2(1), 22-44.

Luining, M. (2017). The challenge of the Visegrad Group: Benefiting from its positions in the EU's coalition patterns. Foreign Policy Review. Institute for Foreign Affairs and Trade, 10, 31-54. 
Machacek, L. (2011). Slovak Republic and its Hungarian ethnic minority: Sociological reflections. Slovak Journal of Poitical Sciences, 11(3), 187-194. Maurice, E. (2019). Refugee quotas 'unacceptable' for Visegrad States. EUOBSERVER, 4 Eylül 2015, https://euobserver.com/migration/130122, (Erişim Tarihi: 10 Temmuz 2019).

Metin, Y. and Ümmühan K. (2011). Avrupa Birliği'nde temel hakların korunması ve Lizbon Antlaşması'nın getirdiği yenilikler. S. D. Ü. Hukuk Fakültesi Dergisi, 1(1), 125-158.

Minıstry Of Foreign Affairs Republıc Of Poland. (2019). Weimar triangle, https://www.msz.gov.pl/en/foreign_policy/europe/wweimar_triangle1/weima r_triangle, (Erişim Tarihi: 16 Mart 2019).

Ministry Of Foreign Affairs Republic Of Poland. (2019). Visegrad Group, https://www.msz.gov.pl/en/foreign_policy/europe/visegrad_group/. (Erişim Tarihi: 15 Temmuz 2019).

Ministry Of Foreign Affairs Of The Czech Republic. (2019). Visegrad Cooperation, https://www.mzv.cz/jnp/en/foreign_relations/visegrad_group/index.html, (Erişim Tarihi: 15 Temmuz 2019).

Minıstry Of Foreign And European Affairs Of The Slovak Republic, (2019). Slovakia and V4, https://www.mzv.sk/web/en/slovakia_and_v4, (Erişim Tarihi: 15 Temmuz 2019).

Muller, R. (2015). Sobotka: Czechs Would benefit from Eurozone Membership, Euractiv, 1 Haziran 2015, https://www.euractiv.com/section/centraleurope/news/sobotka-czechs-would-benefit-from-eurozone-membership/, (Erişim Tarihi: 13 Temmuz 2019).

Naegele, J. (2002). Czech Republic: The benes decrees - how did they come to be and what do they mandate? RadioFreeEurope RadioLiberty, 1 Mart 2002, https://www.rferl.org/a/1098965.html, (Erişim Tarihi: 10 Temmuz 2019).

Nic, M. (2016). The Visegrad Group in the EU: 2016 As A Turning-Point?. European View, 15(2), 281-290.

Norsk Senter For Forskningsdata. (2019). Czech Republic political parties, https://nsd.no/european_election_database/country/czech_republic/parties.ht ml, (Erişim Tarihi: 13 Nisan 2019).

Poláčková, H. (1994). Regional cooperation in Central Europe: Poland, Hungary, Czech Republic and Slovakia: From Visegrad to CEFTA. Perspectives, 3, 117-129. 
Saral, E. (2010). Slovakya'daki macar azınlık ve bunun Slovakya-Macaristan ilişkilerine etkisi. T.C. Türk İş birliği ve Kalkınma İdaresi Başkanlı̆̆̆, Avrupa Etüdleri, s.151-157.

Sarnyal, G. (2019). The Euro in Hungary: Not happening anytime soon, Hungary Today, https://hungarytoday.hu/the-euro-in-hungary-nothappening-anytime-soon/, (Erişim Tarihi: 13 Temmuz 2019).

Schmidt, A. (2016). Frieds forever? The role of the Visegrad Group and European integration. Politics in Central Europe, 12(3), 113-140.

Schopflın, G. (2016). Political lessons for Central Europe from Orbán's Hungary, Aspen Review, Say1 02 , https://www.aspenreview.com/article/2017/political-lessons-for-centraleurope-from-orbans-hungary/, (8 Temmuz 2019).

Shah, S. (2019). Poland rules out Euro adoption, Emerging Europe, 17 Nisan 2019, https://emerging-europe.com/news/poland-rules-out-euro-adoption/, (Erişim Tarihi: 13 Temmuz 2019).

Sonyal, G. (2019). The Hungarian population decline shows no sign of slowing down. Hungary Today, https://hungarytoday.hu/the-hungarian-populationdecline-shows-no-sign-of-slowing-down/, (Erişim Tarihi: 10 Nisan 2019).

Sputnık News. (2018). Çekya'da seçimleri bir kez daha zeman kazandı, https://tr.sputniknews.com/avrupa/201801271031995436-cekyadacumhurbaskanligi-secimlerini-zeman-kazandi/, (Erişim Tarihi: 10 Haziran 2019).

Štépánovský, J. (1994/1995). Cooperation within the Central European Visegrad Group: A Czech Perspective. Perspectives, 4, 91-98.

Strážay, T. (2018). Towards a sustainable Visegrad: Some reflections on the future role of Central Europe in the EU. Understanding Central Europe, Editörler: Marcin Moskalewicz \& Wojciech Przybylski, Routledge, New York, s.115-118.

Szlágyi, I. M. (2014). Problems and future possibilities of Visegrad Cooperation. AARMS, 13(2), 295-304.

Taylor, A. (2016). The Czech Republic is getting a new name: Czechia, The Washington Post, 15 Nisan 2016, https://www.washingtonpost.com/news/worldviews/wp/2016/04/15/theczech-republic-is-getting-a-new-nameczechial?noredirect $=$ onEutm_term $=.30 f c 99 c d 591 f, \quad$ (Erişim Tarihi: 20 Temmuz 2019). 
The World Bank. (2019). Czech Republic Population, https://data.worldbank.org/country/czech-republic, (Erişim Tarihi: 10 Nisan 2019).

The World Bank. (2019). Hungary Population, https://data.worldbank.org/country/hungary, (Erişim Tarihi: 19 Mart 2019).

The World Bank. (2019). Poland Population, https://data.worldbank.org/country/poland, (Erişim Tarihi: 19 Mart 2019).

The World Bank. (2019). "Slovak Republic Population", https://data.worldbank.org/country/slovak-republic, (Erişim Tarihi: 21 Mart 2019).

The World Bank. (2018). 2018 GNI Datas for Germany, https://data.worldbank.org/indicator/NY.GNP.MKTP.CD?end=2018\&locati ons $=$ DEEstart $=2018 \mathcal{E}$ view =bar, (Erişim Tarihi: 16 Mart 2019).

The World Bank. (2018). 2018 GNI Datas for Poland, Czech Republic, Hungary, Slovak Republic, https://data.worldbank.org/indicator/NY.GNP.MKTP.CD?end=2018Elocati ons=PL-HU-CZ-SKEstart=2018Eview=bar, (Erişim Tarihi: 16 Mart 2019).

Tianping, K. (2017). The Role of Visegrad Group and Its Prospect: An Outsider's View. Foreign Policy Review, Institute for Foreign Affairs and Trade, 10, 55-72.

Torö, C., Eamonn B. and Károly G. (2014). Visegrad: The evolving pattern of coordination and partnership after EU Enlargement. Europe-Asia Studies, 66(3), 364-393.

Türkiye Cumhuriyeti Avrupa Birliği Bakanlığı. (2016). Avrupa Birliği Bütçesi, Ankara, s.10, https://www.ab.gov.tr/files/EMPB/ab_butcesi.pdf, (Erişim Tarihi: 22 Haziran 2019).

Türkiye Cumhuriyeti Dışişleri Bakanlığı. (2019). Lizbon Antlaşması, http://www.mfa.gov.tr/lizbon-antlasmasi.tr.mfa, (Erişim Tarihi: 12 Temmuz 2019).

Türkiye Cumhuriyeti Ticaret Bakanlığı. (2018). Brexit Çekya'yı ve Bölgeyi Nasıl Etkileyecek, 16.11.2018, https://ticaret.gov.tr/blog/ulkelerden-ticarihaberler/cek-cumhuriyeti/brexit-cekyayi-ve-bolgeyi-nasil-etkileyecek, (Erişim Tarihi: 10 Nisan 2019). 
Türkiye Cumhuriyeti Ticaret Bakanlığı. (2019). Çekya'da Brexit Endişesi, 17.01.2019, https://www.ticaret.gov.tr/blog/ulkelerden-ticari-haberler/cekcumhuriyeti/cekyada-brexit-endisesi, (Erişim Tarihi: 13 Nisan 2019).

Wahl, P. (2017). Between Eurotopia and Nationalism: A Third Way fort he Future of the EU, Globalizations, Cilt 14, Sayı 1, s.157-163.

Witte, G. (2019). Hungary's Viktor Orban has bashed Europe for years. Will Europe's most important political party finally kick him out?, The Washington Post, https://www.washingtonpost.com/world/europe/hungarysviktor-orban-has-bashed-europe-for-years-will-europes-most-importantpolitical-party-finally-kick-him-out/2019/03/17/66fb7430-402d-11e9-85ad779ef05fd9d8_story.html?noredirect=onEutm_term $=.37611$ be $54 f a 7$ (Erişim Tarihi: 19 Mart 2019).

Visegrad Fund. (2019). Conference of Ministers, https://www.visegradfund.org/about-us/conference-of-ministers/, (Erişim Tarihi: 22 Haziran 2019).

Visegrad Fund. (2019). Council of Ambassadors, https://www.visegradfund.orglabout-us/council-of-ambassadors/, (Erişim Tarihi: 22 Haziran 2019).

Visegrad Fund. (2019). Visegrad Fund, https://www.visegradfund.org/aboutus/the-fund/, (Erişim Tarihi: 22 Haziran 2019).

Visegrad Fund. (2019). About the Visegrad Group, http://www.visegradgroup.eulabout, (Erişim Tarihi: 10 Mart 2019).

Visegrad Fund. (2019). History of the Visegrad Group, http://www.visegradgroup.eu/about/history, (Erişim Tarihi: 8 Temmuz 2019).

Visegrad Fund. (2019). Presidency Programs, http://www.visegradgroup.eu/documents/presidency-programs, (Erişim Tarihi: 16 Temmuz 2019).

\section{Kaynakça Bilgisi / Citation Information}

Yeşiltaş, S. ve Erdem, T. (2021). Vişegrad grubu üzerine bir analiz: Oluşumu, işleyişi, etkileri ve sorunlar. OPUS-Uluslararası Toplum Araştırmaları Dergisi, 18(40), 2961-2998. DOI: 10.26466/opus. 871140 . 